\title{
Deacidification of Cranberry Juice Reduces Its Antibacterial Properties against Oral Streptococci but Preserves Barrier Function and Attenuates the Inflammatory Response of Oral Epithelial Cells
}

\author{
Geneviève Pellerin ${ }^{1,2}\left(\mathbb{D}\right.$, Laurent Bazinet ${ }^{1,2} \mathbb{D}$ and Daniel Grenier ${ }^{3, *}$ \\ 1 Institute of Nutrition and Functional Foods (INAF), Department of Food Sciences, Université Laval, \\ Quebec City, QC G1V 0A6, Canada; genevieve.pellerin.3@ulaval.ca (G.P.); \\ Laurent.bazinet@fsaa.ulaval.ca (L.B.) \\ 2 Laboratoire de Transformation Alimentaire et Procédés ÉlectroMembranaires (LTAPEM, Laboratory \\ of Food Processing and ElectroMembrane Processes), Université Laval, Quebec City, QC G1V 0A6, Canada \\ 3 Oral Ecology Research Group, Faculty of Dentistry, Université Laval, Quebec City, QC G1V 0A6, Canada \\ * Correspondence: daniel.grenier@greb.ulaval.ca
}

check for updates

Citation: Pellerin, G.; Bazinet, L.; Grenier, D. Deacidification of Cranberry Juice Reduces Its Antibacterial Properties against Oral Streptococci but Preserves Barrier Function and Attenuates the Inflammatory Response of Oral Epithelial Cells. Foods 2021, 10, 1634. https://doi.org/10.3390/ foods10071634

Academic Editor: Laura Jaime

Received: 18 May 2021

Accepted: 10 July 2021

Published: 15 July 2021

Publisher's Note: MDPI stays neutral with regard to jurisdictional claims in published maps and institutional affiliations.

Copyright: (c) 2021 by the authors. Licensee MDPI, Basel, Switzerland. This article is an open access article distributed under the terms and conditions of the Creative Commons Attribution (CC BY) license (https:// creativecommons.org/licenses/by/ $4.0 /)$

\begin{abstract}
Cranberry (Vaccinium macrocarpon) may be a potent natural adjuvant for the prevention of oral diseases due to its anti-adherence, anti-cariogenic, and anti-inflammatory properties. However, the high titrable acidity of cranberry juice (CJ) has been reported to cause gastrointestinal discomfort, leading consumers to restrict their intake of this beverage. Electrodialysis with a bipolar membrane $(\mathrm{EDBM})$ can reduce the organic acid content of $\mathrm{CJ}$ while retaining the flavonoids associated with potential health benefits. This study aimed to assess how the deacidification of CJ by EDBM impacts the antibacterial properties of the beverage against cariogenic (Streptococcus mutans, Streptococcus sobrinus) and commensal (Streptococcus gordonii, Streptococcus oralis, Streptococcus salivarius) streptococci, and how it affects oral epithelial barrier function and inflammatory response in an in vitro model. The removal of organic acids from $C J$ (deacidification rate $\geq 42 \%$ ) reduced the bactericidal activity of the beverage against planktonic S. mutans and S. gordonii after a 15-min exposure, whereas only the viability of $S$. gordonii was significantly impacted by CJ deacidification rate when the bacteria were embedded in a biofilm. Moreover, conditioning saliva-coated hydroxyapatite with undiluted CJ samples significantly lowered the adherence of S. mutans, S. sobrinus, and S. oralis. With respect to epithelial barrier function, exposure to $C J$ deacidified at a rate of $\geq 19 \%$ maintained the integrity of a keratinocyte monolayer over the course of $24 \mathrm{~h}$ compared to raw $\mathrm{CJ}$, as assessed by the determination of transepithelial electrical resistance (TER) and fluorescein isothiocyanate-conjugated dextran paracellular transport. These results can be in part attributed to the inability of the deacidified CJ to disrupt two tight junction proteins, zonula occludens -1 and occludin, following exposure, unlike raw CJ. Deacidification of CJ impacted the secretion of IL-6, but not of IL-8, by oral epithelial cells. In conclusion, deacidification of $\mathrm{CJ}$ appears to provide benefits with respect to the maintenance of oral health.
\end{abstract}

Keywords: oral streptococci; dental caries; epithelial barrier; electrodialysis; cranberry juice; antibacterial; organic acids; inflammation

\section{Introduction}

Over 700 bacterial species have been detected in the oral cavity. Although most pose no threat to the maintenance of oral health, a minority are recognized pathogens [1]. The development of a dental biofilm begins with the establishment of streptococcal species, including Streptococcus mitis, Streptococcus oralis, Streptococcus sanguinis, and Streptococcus gordonii. These early colonizers use a wide variety of surface adhesins to bind to proteinaceous constituents of the acquired salivary pellicle that covers the tooth enamel, then 
firmly adhere to and grow on the tooth surface [2-5]. Although most early colonizers are commensal, they can also serve as anchor points for secondary colonizers, some of which are oral pathogens [4]. Additionally, the accumulation of dental biofilm can disrupt the oral mucosa, which serves as an interface that protects the host from environmental stresses and bacterial invasions of host tissues [6]. The oral epithelium is also regularly challenged by dietary constituents that may contain damaging agents. Preserving the integrity of the oral mucosa by limiting the build-up of dental biofilm and by consuming low stressinducing foods is crucial in order to prevent infections and slow the development of severe oral diseases.

Mutans streptococci, mainly Streptococcus mutans and Streptococcus sobrinus, are key pathogens involved in the onset of dental caries [7-10]. Their acidogenic and aciduric natures give them a competitive advantage in the development of carious lesions. Their ability to form insoluble glucans from dietary sucrose via glucosyltransferases (GTFs) allows them to bind strongly and secure their attachment to tooth surfaces [11]. These enzymes also support the formation of a compact exopolysaccharide (EPS) matrix that limits compound diffusion. Lactate, which is abundantly produced from sugar by mutans streptococci, accumulates locally, causing a pH drop and enamel demineralization [4,12].

The American cranberry (Vaccinium macrocarpon), which is mainly consumed in the form of cranberry juice (CJ) [13], is regarded as a promising functional food for the prevention of chronic diseases such as cancer, heart diseases, type 2 diabetes, and oral diseases [14-17]. More specifically, the phenolic compounds of this berry, which include A-type proanthocyanidins (PACs), possess many bioactivities that can hinder the development of dental caries. Both CJ and cranberry phenolic extracts have been described as effective inhibitors of GTFs in mutans streptococci [18-21]. The inhibition of GTFs prevents the development of cariogenic biofilms in vitro and in vivo [18-21]. Moreover, the reported ability of cranberry polyphenols to block bacterial coaggregation could hamper the accumulation of dental plaque [22]. Cranberry polyphenols also lower the aciduricity of S. mutans by inhibiting the proton-translocating $\mathrm{F}_{1} \mathrm{~F}_{0}$-ATPase activity that allows $S$. mutans to maintain an active metabolism under acidic stress [18,19].

Electrodialysis with bipolar membrane (EDBM), an electromembrane process, has recently been successfully used at a semi-industrial scale for the deacidification of CJ without altering the phenolic profile of the juice [23]. Aside from the ecoefficiency of EDBM [24], the benefit of this process lies in the selective removal of citric acid (CA) and malic acid (MA) from CJ [23,25], which are responsible for the gastrointestinal discomfort reported when the raw beverage is consumed $[26,27]$ and contribute to enamel demineralization $[28,29]$. For instance, a CJ deacidification rate (DR) of $\geq 37 \%$ reached by EDBM, which translates into a $\geq 37 \%$ reduction in titratable acidity, significantly preserves the integrity of an intestinal epithelial barrier in an in vitro model [30]. This has been mainly associated with the removal of CA [31].

The present study investigated how the deacidification rate of CJ obtained by EDBM affects the potential benefits of the juice regarding the prevention of dental caries and the maintenance of the oral epithelial barrier. The specific objectives of the present study were to investigate how EDBM deacidification of CJ impacts (1) antibacterial activities against oral streptococci, (2) the barrier function of oral epithelial cells, and (3) the inflammatory response of oral epithelial cells.

\section{Materials and Methods}

\subsection{Cranberry Juice}

Pasteurized and clarified CJ produced from fresh fruits was obtained from Fruit d'Or (Plessisville, QC, Canada). The cranberry juice was kept frozen at $-30^{\circ} \mathrm{C}$, and was thawed at $4{ }^{\circ} \mathrm{C}$ before deacidification. 


\subsubsection{Deacidification of Cranberry Juice}

EDBM was performed using a EUR $-2 C$ cell (Eurodia, Pertuis, France) with a total effective surface area of $0.14 \mathrm{~m}^{2}$. The EDBM configuration used has been described by Faucher et al. [23]. Deacidified CJ samples were collected at DRs of $0 \%$ (raw), $19 \%, 42 \%$, $60 \%$, and $79 \%$, as calculated from titratable acidity measurements, and were analyzed for their physicochemical composition (see below). A sample of raw CJ diluted in distilled water (dilution factor of 4) was included in the study given that consumers are advised to dilute non-deacidified $\mathrm{CJ}$ before consumption to avoid gastrointestinal discomfort and other adverse effects. All the CJ samples were filter-sterilized prior to use.

\subsubsection{Analysis}

Titratable Acidity

The titratable acidity of the raw and deacidified CJ samples was measured as described in AOAC method 942.15 [32]. Briefly, the CJ samples were diluted with degassed distilled water, and were then titrated with $0.1 \mathrm{M} \mathrm{NaOH}$ until a $\mathrm{pH}$ of 8.2 was reached. Titratable acidity is expressed as $\mathrm{g} / \mathrm{L}$ of citric acid monohydrate equivalents.

\section{Organic Acid Content}

Organic acids were extracted from the CJ samples using C18-SPE cartridges (nonendcapped, $6 \mathrm{~mL}, 500 \mathrm{mg}$; Silicycle, Quebec City, QC, Canada). The cartridges were first conditioned with $5 \mathrm{~mL}$ of methanol and were then rinsed with $5 \mathrm{~mL}$ of distilled water followed by $10 \mathrm{~mL}$ of a 1:1 acetonitrile:water solution. The cartridges were vacuum-dried, and $10 \mathrm{~mL}$ of each CJ sample was passed through the cartridges.

The concentrations of quinic acid (QA), citric acid (CA), and malic acid (MA) were determined by HPLC analysis as described in AOAC method 986.13 [33]. Samples (10 $\mu \mathrm{L})$ were injected on a Synergi Hydro-RP80A column $(250 \times 4.6 \mathrm{~mm}$; Phenomenex, Torrance, CA, USA) at room temperature using a $\mathrm{KH}_{2} \mathrm{PO}_{4}$ solution $(0.2 \mathrm{M}, \mathrm{pH} 2.4)$ as an isocratic mobile phase. An Agilent 1100 series HPLC system equipped with a UV detector (wavelength set at $214 \mathrm{~nm}$ ) was used to separate and detect the organic acids. Calibration curves and the retention times of authentic standards of QA, CA, and MA (Sigma Aldrich, Saint-Louis, $\mathrm{MO}$, USA) were used to quantify and identify the organic acids.

\section{Anthocyanin Content}

The anthocyanin content of the raw and deacidified CJ samples was measured as described by Wu and Prior [34]. The CJ samples were filtered through $0.45 \mu \mathrm{m}$ nylon filters, and $20 \mu \mathrm{L}$ volumes were injected on a Zorbax SB-C18 $5 \mu \mathrm{m}$ column $(250 \times 4.6 \mathrm{~mm}$, Agilent, Santa Clara, CA, USA) at room temperature. Anthocyanins were eluted with $1 \mathrm{~mL} / \mathrm{min}$ of two solvents (solvent A: $95 \%$ water $/ 5 \%$ formic acid and solvent B: $100 \%$ methanol). An Agilent 1100 series system equipped with a diode array detector (wavelength set at $520 \mathrm{~nm}$ ) was used to quantify the anthocyanin content. Results are expressed in $\mathrm{mg} / \mathrm{L}$ of cyanidin-3-glucoside equivalents.

\section{Proanthocyanidin Content}

Prior to the determination of the PAC profile, raw and deacidified CJ samples were filtered through $0.45 \mu \mathrm{m}$ nylon filters. The PACs were quantified as described by Khanal et al. [35]. An Agilent 1260 series HPLC system equipped with a fluorescence detector (emission wavelength: $321 \mathrm{~nm}$, excitation wavelength: $230 \mathrm{~nm})$ was used. Samples $(5 \mu \mathrm{L})$ were injected on a Develosil 100 Diol-5 column $(250 \times 4.6 \mathrm{~mm}$; Nomura Chemical Co., Ltd., Kasugai, Japan) at $35^{\circ} \mathrm{C}$. The PACs were eluted based on their degree of polymerization using $0.8 \mathrm{~mL} / \mathrm{min}$ of two solvents (Solvent A: $98 \%$ acetonitrile/2\% acetic acid; Solvent B: $95 \%$ methanol $/ 3 \%$ water $/ 2 \%$ acetic acid). An epicatechin calibration curve was used to quantify the PACs using a correction factor to convert the different response factors of monomeric to polymeric PACs. Results are expressed as $\mathrm{mg} / \mathrm{L}$ of epicatechin equivalents. 
Total Phenolic Compounds

The concentration of total phenolic compounds was measured using the microscale Folin-Ciocalteu assay [36]. Absorbance was measured using an xMark Microplate spectrophotometer (Bio-Rad Laboratories Inc., Mississauga, ON, Canada) at $765 \mathrm{~nm}$. Results are expressed as $\mathrm{mg} / \mathrm{L}$ of gallic acid equivalents.

\section{Sugar Content}

The sugar content of the raw and deacidified CJ samples was determined using the Somogyi-Nelson method at the microplate scale [37]. Absorbance was measured with an xMark Microplate spectrophotometer at $490 \mathrm{~nm}$. Results are expressed as $\mathrm{g} / \mathrm{L}$ of glucose equivalents.

\subsection{Bacteria and Growth Conditions}

Two cariogenic bacterial species (Streptococcus mutans ATCC 25175 and Streptococcus sobrinus ATCC 33478) and three commensal bacterial species (Streptococcus gordonii ATCC 12559, Streptococcus oralis ATCC 35037, and Streptococcus salivarius K12) were included in the present study. All streptococcal species were grown aerobically at $37^{\circ} \mathrm{C}$ in Brain Heart Infusion broth (BHI; BBL Microbiology Systems, Cockeysville, MD, USA) supplemented with $0.5 \%(w / v)$ glucose.

\subsection{Bactericidal Activity against Planktonic Streptococci}

The ability of raw and deacidified CJs to kill planktonic streptococci on direct contact was investigated using the NF EN 1040 protocol for disinfectants and antiseptics [38]. First, $10 \mathrm{~mL}$ of a $24 \mathrm{~h}$ culture was vortexed with $200 \mathrm{mg}$ of sterile glass beads $(0.3-0.5 \mathrm{~mm})$ to break bacterial chains. The culture was diluted in fresh BHI supplemented with $0.5 \%$ glucose to an optical density at $660 \mathrm{~nm}\left(\mathrm{OD}_{660}\right)$ of 0.2 . Then, $100 \mu \mathrm{L}$ of the bacterial suspension was added to $900 \mu \mathrm{L}$ of each of the $\mathrm{CJ}$ samples at room temperature. The bacteria were exposed to the CJ samples for $0 \mathrm{~min}$ (initial count), $1 \mathrm{~min}$, and $15 \mathrm{~min}$, following which $100 \mu \mathrm{L}$ of the inoculated CJ samples were added to $900 \mu \mathrm{L}$ of dilution buffer $(0.85 \% \mathrm{NaCl}$, $0.01 \%$ tryptone; $\mathrm{pH} 7.0)$. Ten-fold serial dilutions $\left(10^{-3}\right.$ to $\left.10^{-7}\right)$ were prepared, and $100 \mu \mathrm{L}$ of each dilution was plated on triplicate BHI agar plates supplemented with $0.5 \%$ glucose. Dilution buffer was used as a negative control, and chlorhexidine (CHX; $0.12 \%$ ) was used as a positive control. The plates were incubated for $72 \mathrm{~h}$ at $37^{\circ} \mathrm{C}$ and colony-forming units (CFU) were determined. Only plates with between 25 and 250 CFU were considered. The experiment was repeated twice.

\subsection{Bactericidal Activity against Biofilm-Embedded Streptococci}

The effect of removing organic acids from $\mathrm{CJ}$ on its bactericidal activity against biofilmembedded streptococci was assessed using FilmTracer LIVE/DEAD Biofilm Viability kit (Life Technologies Corporation, Eugene, OR, USA) according to the manufacturer's protocol, with slight modifications. The optical density of a $24 \mathrm{~h}$ bacterial culture was adjusted to $\mathrm{OD}_{660}=0.1$, and $100 \mu \mathrm{L}$ were added to the wells of a 96-well clear bottom black wall microplate (Greiner Bio-One North America, Monroe, NC, USA). The microplate was incubated $24 \mathrm{~h}$ at $37^{\circ} \mathrm{C}$ to allow for biofilm formation. Spent medium and unattached bacteria were removed by aspiration, and the preformed biofilms were exposed to $100 \mu \mathrm{L}$ of the CJ samples for $1 \mathrm{~min}$ and $15 \mathrm{~min}$. The CJ was removed by aspiration, and the biofilms were washed once with $100 \mu \mathrm{L}$ of Hanks' Balanced Salt Solution (HBSS; pH 7.2). The biofilms were then treated with $50 \mu \mathrm{L}$ of a fresh solution of $3 \mu \mathrm{L} / \mathrm{mL}$ of SYTO 9 green (3.34 $\mathrm{mM}$ ) and $3 \mu \mathrm{L} / \mathrm{mL}$ of propidium iodide (PI; $20 \mathrm{mM}$ ) in HBSS for $30 \mathrm{~min}$ at room temperature in the dark. The biofilms were rinsed twice with distilled water. Distilled water $(100 \mu \mathrm{L})$ was added to each well, and relative fluorescence units (Ex: $485 \mathrm{~nm} / \mathrm{Em}: 528 \mathrm{~nm}$ for SYTO 9 green, and Ex: $485 \mathrm{~nm} / \mathrm{Em}$ : $590 \mathrm{~nm}$ for PI) were recorded using a Synergy 2 microplate reader (BioTek Instruments, Winooski, VT, USA). Phosphate-buffered saline (PBS; $\mathrm{pH} 7.2$ ) and $0.12 \% \mathrm{CHX}$ were used as negative and positive controls, respectively. 


\subsection{Bacterial Adherence to Hydroxyapatite}

To assess the adherence of streptococci to saliva-coated hydroxyapatite (HA) preconditioned with CJs, the bottoms of the wells of a 96-well black bottom black wall microplate (Greiner Bio-One North America) were coated with HA according to the protocol described by Shahzad et al. [39]. Briefly, $60 \mu \mathrm{L}$ of an HA suspension $(10 \% w / v$, in acetone) was added to each well, and the microplate was incubated at $37^{\circ} \mathrm{C}$ for $15 \mathrm{~min}$ under constant agitation. The wells were then washed twice with distilled water and once with PBS and were left to dry overnight at $37^{\circ} \mathrm{C}$. Artificial saliva was prepared as described by Madhwani and McBain [40], and $100 \mu \mathrm{L}$ was added to the HA-coated wells. After 30 min, excess saliva was removed by aspiration, and the HA was preconditioned by adding $100 \mu \mathrm{L}$ of $\mathrm{CJ}$ sample to each well.

Bacterial cells from a $24 \mathrm{~h}$ culture were labelled with fluorescein isothiocyanate (FITC) as described by Ben Lagha et al. [41]. FITC-labelled bacteria were suspended in PBS to obtain an $\mathrm{OD}_{660}$ of 1 . Following a 5 min pretreatment of HA-coated wells with the CJ samples, $100 \mu \mathrm{L}$ of bacterial culture was added to the wells, and the microplate was incubated at $37^{\circ} \mathrm{C}$ for $1 \mathrm{~h}$ in the dark. The bacteria were removed by aspiration. The wells were washed twice with PBS, and $100 \mu \mathrm{L}$ of distilled water was added to each well. Fluorescence units of each wells were measured using a Synergy 2 microplate reader with the excitation wavelength set at $485 \mathrm{~nm}$ and emission wavelength set at $528 \mathrm{~nm}$. Relative fluorescence units (\%) for each treatment were calculated based on the values obtained for the negative control (PBS). Wells with no bacteria were included to determine basal autofluorescence.

\subsection{Transepithelial Electrical Resistance of Oral Epithelial Barrier}

To determine whether exposure to raw and deacidified CJs disrupts the oral epithelial barrier, the immortalized gingival keratinocyte cell line B11, which was previously characterized by Groeger, Michel and Meyle [42], was used to determine tight junction integrity by monitoring transepithelial electrical resistance (TER). The B11 cells were grown at $37^{\circ} \mathrm{C}$ in a $5 \% \mathrm{CO}_{2}$ atmosphere in keratinocyte-serum free medium (K-SFM) supplemented with $50 \mu \mathrm{g} / \mathrm{mL}$ of bovine pituitary extract, $5 \mathrm{ng} / \mathrm{mL}$ of human epidermal growth factor, $100 \mu \mathrm{g} / \mathrm{mL}$ of penicillin G-streptomycin, and $2.5 \mu \mathrm{g} / \mathrm{mL}$ of amphotericin B. The B11 cells were seeded at $3.5 \times 10^{5}$ cells/insert in Costar Transwell clear polyester membrane inserts (6.5-mm diameter; $0.4 \mu \mathrm{m}$ pore size; Corning Co., Cambridge, MA, USA). Supplemented K-SFM was added to the apical $(100 \mu \mathrm{L})$ and basolateral $(600 \mu \mathrm{L})$ chambers, and the plate was incubated for $48 \mathrm{~h}$ at $37{ }^{\circ} \mathrm{C}$ in a $5 \% \mathrm{CO}_{2}$ atmosphere. The growth medium was then replaced with the same volume of antibiotic-free K-SFM, and the plate was incubated for a further $24 \mathrm{~h}$ at $37{ }^{\circ} \mathrm{C}$ in a $5 \% \mathrm{CO}_{2}$ atmosphere to ensure the complete formation of tight junctions. The apical compartment was then filled with $100 \mu \mathrm{L}$ of raw or deacidified CJ. After 5 min the CJ was removed by aspiration, and $100 \mu \mathrm{L}$ of antibiotic-free K-SFM was added. The plate was incubated at $37^{\circ} \mathrm{C}$ in a $5 \% \mathrm{CO}_{2}$ atmosphere for the duration of the experiment. TER values were measured using an ohm/voltmeter (EVOM2; World Precision Instruments, Sarasota, FL, USA) at time 0 (initial resistance; before treatment with CJs) and after $1 \mathrm{~h}, 2 \mathrm{~h}, 6 \mathrm{~h}$, and $24 \mathrm{~h}$. The results were converted into Ohms $(\Omega) / \mathrm{cm}^{2}$ by multiplying the resistance with the membrane surface area. A $100 \%$ value was attributed to the initial resistance (prior to CJ exposure). The TER measurements are expressed as percentages of the initial TER. The measurements were done in triplicate for each treatment, and the assay was repeated in triplicate. Representative results from one assay are presented.

\subsection{Fluorescein Isothiocyanate-Conjugated Dextran (FD-4) Transport}

The integrity of the oral epithelial barrier was also assessed by measuring the paracellular transport of FITC-conjugated $4.4 \mathrm{kDa}$ dextran (FD-4; Sigma-Aldrich Canada Ltd.) according to a previously described protocol [41]. Briefly, B11 cells were seeded at $3.5 \times 10^{5}$ cells/insert on Costar Transwell clear polyester membrane inserts $(6.5 \mathrm{~mm}$ diameter; $0.4 \mu \mathrm{m}$ pore size; Corning Co.) and were treated with CJs as described above. FD-4 (100 $\mu \mathrm{L}$, 
$1 \mathrm{mg} / \mathrm{mL}$ in K-SFM) and $1.2 \mathrm{~mL}$ of K-SFM were added to the apical and basolateral compartments, respectively. Fluorescence in the basolateral chamber was monitored at time 0 and after $1 \mathrm{~h}, 2 \mathrm{~h}, 8 \mathrm{~h}$, and $24 \mathrm{~h}$ using a Synergy 2 microplate reader with the excitation and emission wavelengths set at $485 \mathrm{~nm}$ and $528 \mathrm{~nm}$, respectively. The experiment was repeated in triplicate. Representative results from one experiment are presented.

\subsection{Immunofluorescent Staining of Zonula Occludens-1 and Occludin}

Keratinocytes exposed to raw or deacidified $\mathrm{CJ}$ for $5 \mathrm{~min}$ were immunostained for zonula occludens -1 (ZO-1) and occludin, two tight junction proteins. B11 keratinocytes were seeded at $3.5 \times 10^{5}$ cells/insert on Costar Transwell clear polyester membrane inserts (6.5-mm diameter; $0.4 \mu \mathrm{m}$ pore size; Corning Co.) and were treated with CJ samples as described in Section 2.6. Following a $4 \mathrm{~h}$ exposure to CJs, the cells were fixed with $100 \mu \mathrm{L}$ of paraformaldehyde (4\% in PBS; Thermo Fisher Scientific, Waltham, MA, USA) at $4{ }^{\circ} \mathrm{C}$ for $10 \mathrm{~min}$. The cells were permeabilized by incubating them with $0.1 \%$ Triton $\mathrm{X}-100$ $(100 \mu \mathrm{L})$ for $8 \mathrm{~min}$. After three washes with PBS, $200 \mu \mathrm{L}$ of freshly prepared blocking buffer ( $3 \%$ skim milk powder, $20 \mathrm{mM}$ Tris hCl [pH 8], $150 \mathrm{mM} \mathrm{NaCl}$, and $0.5 \%$ Tween 20) was added to the apical chamber and left for $30 \mathrm{~min}$, at $4{ }^{\circ} \mathrm{C}$. Tight junction proteins were stained with $100 \mu \mathrm{L}$ of either $13 \mu \mathrm{g} / \mathrm{mL}$ of occludin antibody-Alexa Fluor 488 conjugate or $6.5 \mu \mathrm{g} / \mathrm{mL}$ of ZO-1 antibody-Alexa Fluor 594 conjugate (Invitrogen, Waltham, MA, USA) diluted in blocking buffer. The cells were incubated overnight at $4{ }^{\circ} \mathrm{C}$ in the dark and were then treated with ProLong Diamond antifade (Life Technologies). An Olympus FSX100 fluorescence microscope and FSX-BSW imaging software (Olympus, Tokyo, Japan) were used to visualize stained ZO-1 and occludin.

\subsection{Production of IL- 6 and IL-8 by Oral Epithelial Cells}

To determine whether the removal of organic acids from CJ affected the inflammatory response, GMSM-K oral epithelial cells, which were previously characterized by Gilchrist et al. [43], were seeded at $1.0 \times 10^{6}$ cells $/ \mathrm{mL}$ in 12-well tissue-culture treated microplates (Sarstedt Inc., Montreal, QC, Canada). The GMSM-K epithelial cell line was used for this assay as it is a producer of pro-inflammatory cytokines, unlike B11 epithelial cells. Following an overnight incubation at $37^{\circ} \mathrm{C}$ in a $5 \% \mathrm{CO}_{2}$ atmosphere, the growth medium was removed by aspiration, and the cells were exposed to $1 \mathrm{~mL}$ of raw $\mathrm{CJ}$ or deacidified $\mathrm{CJ}$ for $5 \mathrm{~min}$ at room temperature. A preliminary MTT assay showed that this contact time did not significantly decrease cell viability. The CJ samples were removed by aspiration, and $1 \mathrm{~mL}$ of DMEM supplemented with $1 \%$ FBS was added to the wells. The cells were incubated at $37^{\circ} \mathrm{C}$ for $24 \mathrm{~h}$ in a $5 \% \mathrm{CO}_{2}$ atmosphere. The cell-free culture supernatants were then collected and were kept at $-20{ }^{\circ} \mathrm{C}$ until used. IL- 6 and IL-8 concentrations in the supernatants were determined using enzyme-linked immunosorbent assay (ELISA) kits (eBioscience Inc., San Diego, CA, USA) according to the manufacturer's protocols.

\subsection{Statistical Analysis}

Unless specified otherwise, all assays were performed in triplicate. Results are expressed as means \pm standard deviations (SD). The physicochemical compositions of the CJ samples were analyzed using a one-way analysis of variance (ANOVA) with a post hoc Tukey test $(p<0.05)$. Statistical analyses of bacterial adherence to HA and cytokine secretion were performed using a one-way analysis of variance with a post hoc Bonferroni multiple comparison test $(p<0.01)$ (GraphPad Software Inc., La Jolla, CA, USA). For the other assays, a two-way analysis of variance with a post hoc Bonferroni multiple comparison test $(p<0.01)$ was used. 


\section{Results}

\subsection{Composition of the Raw and Deacidified CJs}

EDBM is an electrochemical process that selectively removes CA and MA from CJ, with a reduction in QA content when the DR exceeds $40 \%$ [25]. As can be seen in Table 1, there was a linear decrease in CA and MA throughout the deacidification process, leading to the complete elimination of MA in the CJ sample deacidifed at a rate of $79 \%$. The release of $\mathrm{OH}^{-}$ions in the juice compartment by the bipolar membranes during the process concurrently caused the $\mathrm{pH}$ of the $\mathrm{CJ}$ to increase from 2.6 (raw $\mathrm{CJ}$ ) to 3.2 (DR $79 \%$ ). However, as expected based on the literature $[23,25]$, the concentrations of sugar, total phenolic compounds, anthocyanins, and PACs remained unchanged in all the raw and deacidified CJ samples. The $\mathrm{pH}$ of the $1 / 4$ dilution of raw $\mathrm{CJ}$ was 2.6 (the same as undiluted raw $\mathrm{CJ}$ ), and it was expected that the diluted raw $\mathrm{CJ}$ contained $25 \%$ of the sugar, total phenolic, and organic acid content of raw CJ.

Table 1. Physicochemical composition of the raw and deacidified cranberry juices.

\begin{tabular}{|c|c|c|c|c|c|}
\hline Deacidification Rate (\%) & 0 (raw) & 19 & 42 & 60 & 79 \\
\hline $\mathrm{pH}$ & $2.59 \pm 0.03^{a}$ & $2.74 \pm 0.01^{b}$ & $2.71 \pm 0.01^{b}$ & $2.87 \pm 0.01^{c}$ & $3.24 \pm 0.02^{d}$ \\
\hline $\begin{array}{c}\text { Titrable acidity (g/L of citric } \\
\text { acid monohydrate } \\
\text { equivalents) }\end{array}$ & $9.25 \pm 0.05^{\mathrm{a}}$ & $7.48 \pm 0.02^{b}$ & $5.40 \pm 0.05^{\mathrm{c}}$ & $3.72 \pm 0.02^{d}$ & $1.91 \pm 0.05^{\mathrm{e}}$ \\
\hline $\begin{array}{l}\text { Sugar (g/L of glucose } \\
\text { equivalents) }\end{array}$ & $44.4 \pm 4.7^{\mathrm{a}}$ & $44.1 \pm 6.6^{\mathrm{a}}$ & $44.9 \pm 5.1^{\mathrm{a}}$ & $47.8 \pm 10.3^{a}$ & $53.3 \pm 2.5^{\mathrm{a}}$ \\
\hline \multicolumn{6}{|l|}{ Organic acids (g/L) } \\
\hline Quinic acid & $10.35 \pm 0.31 \mathrm{ab}$ & $10.72 \pm 0.04^{\mathrm{a}}$ & $10.49 \pm 0.17 \mathrm{ab}$ & $10.11 \pm 0.14^{b}$ & $9.19 \pm 0.11^{\mathrm{c}}$ \\
\hline Citric acid & $11.59 \pm 0.20^{\mathrm{a}}$ & $9.49 \pm 0.15^{b}$ & $6.88 \pm 0.15^{c}$ & $4.67 \pm 0.09^{\mathrm{d}}$ & $2.35 \pm 0.06^{\mathrm{e}}$ \\
\hline Malic acid & $6.03 \pm 0.10^{\mathrm{a}}$ & $4.44 \pm 0.04^{\mathrm{b}}$ & $2.40 \pm 0.11^{\mathrm{c}}$ & $1.34 \pm 0.06^{\mathrm{d}}$ & $0.00 \pm 0.00^{\mathrm{e}}$ \\
\hline \multicolumn{6}{|l|}{$\begin{array}{l}\text { Anthocyanins (mg/L of } \\
\text { cyanidin-3-glucoside } \\
\text { equivalents) }\end{array}$} \\
\hline Cyanidin-3-galactoside & $65.14 \pm 0.51^{\mathrm{a}}$ & $65.59 \pm 0.67^{\mathrm{a}}$ & $64.70 \pm 0.32^{\mathrm{a}}$ & $65.76 \pm 1.22^{\mathrm{a}}$ & $61.89 \pm 0.61^{b}$ \\
\hline Cyanidin-3-glucoside & $2.15 \pm 0.12^{\mathrm{a}}$ & $2.97 \pm 0.06^{b}$ & $2.47 \pm 0.10^{c}$ & $2.06 \pm 0.06^{\mathrm{a}}$ & $2.22 \pm 0.19^{\text {a c }}$ \\
\hline Cyanidin-3-arabinoside & $51.12 \pm 0.69^{a}$ & $51.27 \pm 0.15^{\mathrm{a}}$ & $50.99 \pm 0.37^{\mathrm{a}}$ & $50.57 \pm 0.89^{a}$ & $48.24 \pm 0.22^{b}$ \\
\hline Peonidin-3-galactoside & $84.74 \pm 0.54^{\mathrm{a}}$ & $85.91 \pm 0.95^{\mathrm{a}}$ & $83.76 \pm 0.51^{\mathrm{a}}$ & $85.02 \pm 1.21^{\mathrm{a}}$ & $80.74 \pm 0.71^{b}$ \\
\hline Peonidin-3-glucoside & $8.50 \pm 0.10^{\mathrm{a}}$ & $8.86 \pm 0.09 \mathrm{bc}$ & $9.01 \pm 0.12^{b}$ & $8.71 \pm 0.06^{a b c}$ & $8.53 \pm 0.10^{\text {a c }}$ \\
\hline Peonidin-3-arabinoside & $37.94 \pm 0.62^{\mathrm{a}}$ & $38.41 \pm 0.39^{\mathrm{a}}$ & $37.13 \pm 0.36^{\mathrm{a}}$ & $37.29 \pm 0.34^{\mathrm{a}}$ & $35.98 \pm 0.30^{b}$ \\
\hline Total & $249.58 \pm 1.82^{\mathrm{a}}$ & $253.11 \pm 0.94^{\mathrm{a}}$ & $248.05 \pm 0.51^{\mathrm{a}}$ & $249.40 \pm 2.75^{\mathrm{a}}$ & $237.60 \pm 1.47^{b}$ \\
\hline \multicolumn{6}{|l|}{$\begin{array}{l}\text { Proanthocyanidins (mg/L } \\
\text { of epicatechin equivalents) }\end{array}$} \\
\hline Monomers & $39.35 \pm 0.64^{\mathrm{a}}$ & $40.43 \pm 1.35^{\mathrm{a}}$ & $36.05 \pm 2.74^{\mathrm{a}}$ & $36.67 \pm 2.41^{\mathrm{a}}$ & $37.43 \pm 1.97^{\mathrm{a}}$ \\
\hline 2-3mers & $148.36 \pm 1.80^{\mathrm{a}}$ & $155.41 \pm 6.66^{\mathrm{a}}$ & $142.12 \pm 18.47^{\mathrm{a}}$ & $157.39 \pm 3.86^{\mathrm{a}}$ & $159.30 \pm 9.67^{\mathrm{a}}$ \\
\hline $4-6$ mers & $59.92 \pm 1.24^{\mathrm{a}}$ & $62.94 \pm 2.26^{\mathrm{a}}$ & $57.64 \pm 7.06^{\mathrm{a}}$ & $62.55 \pm 1.88^{a}$ & $62.29 \pm 3.58^{a}$ \\
\hline 7-10mers & $4.28 \pm 0.27^{\mathrm{a}}$ & $4.52 \pm 0.35^{\mathrm{a}}$ & $4.06 \pm 0.54^{\mathrm{a}}$ & $4.41 \pm 0.48^{\mathrm{a}}$ & $4.53 \pm 0.50^{\mathrm{a}}$ \\
\hline Polymers & $5.55 \pm 0.52^{\mathrm{a}}$ & $5.60 \pm 0.35^{\mathrm{a}}$ & $5.90 \pm 0.38^{a}$ & $5.88 \pm 0.05^{\mathrm{a}}$ & $5.78 \pm 0.05^{\mathrm{a}}$ \\
\hline Total & $257.46 \pm 2.36^{\mathrm{a}}$ & $268.90 \pm 10.34^{\mathrm{a}}$ & $245.78 \pm 29.00^{a}$ & $266.91 \pm 8.35^{\mathrm{a}}$ & $269.33 \pm 15.61^{a}$ \\
\hline $\begin{array}{c}\text { Total phenolic compounds } \\
\text { (mg/L of gallic acid } \\
\text { equivalents) }\end{array}$ & $1074.79 \pm 4.90^{\mathrm{a}}$ & $1039.65 \pm 28.27^{a}$ & $978.42 \pm 47.79^{a}$ & $1075.52 \pm 34.87^{\mathrm{a}}$ & $984.21 \pm 53.66^{a}$ \\
\hline
\end{tabular}

Results are presented as means $\pm \mathrm{SD}(n=3)$. Results in the same row with different letters for the same parameter are significantly different (Tukey, $p<0.05)$.

\subsection{Bactericidal Activity of the Raw and Deacidified CJs against Planktonic Bacteria}

The bactericidal activity of the raw $\mathrm{CJ}$ and deacidified CJs was evaluated using two cariogenic and three commensal species of oral streptococci. As shown in Figure 1, a short contact time (1 $\mathrm{min}$ ) with the CJ samples did not result in an increase in bactericidal activity for any of the streptococci studied compared to the negative control. However, the susceptibility of the bacteria to the CJ samples differed between species when the 
exposure time was extended to $15 \mathrm{~min}$. While the bactericidal activity of the CJ samples against S. sobrinus (Figure 1B), S. oralis (Figure 1D), and S. salivarius (Figure 1E) were not significantly different from that of the negative control, S. mutans (Figure 1A) and S. gordonii (Figure 1C) populations decreased with the DR of the CJ samples. In the case of $S$. mutans, undiluted raw CJ caused a mean log reduction of 4.36, whereas a $19 \%$ DR CJ caused a 3.80 $\log$ reduction in the viable bacterial population. Neither DRs $\geq 42 \%$ nor a $1 / 4$ dilution of raw CJ exhibited significantly different bactericidal properties compared to the dilution buffer, which suggests that the observed effects are linked to the concentration of organic acids more than to the low $\mathrm{pH}$ of the samples. Similar results were obtained for S. gordonii, which had a bacterial mortality close to that of the control after a 15 min exposure for DRs $\geq 42 \%$. However, a $1 / 4$ dilution of raw $\mathrm{CJ}$ reduced the viability of $S$. gordonii to the same extent as a $19 \%$ DR CJ sample, suggesting the impact of low $\mathrm{pH}$ on the bactericidal activity of the $\mathrm{CJ}$ against this species. CHX, which was used as a positive bactericidal agent, quickly eradicated all the bacteria studied for the two test times (1 $\mathrm{min}$ and $15 \mathrm{~min}$ ).
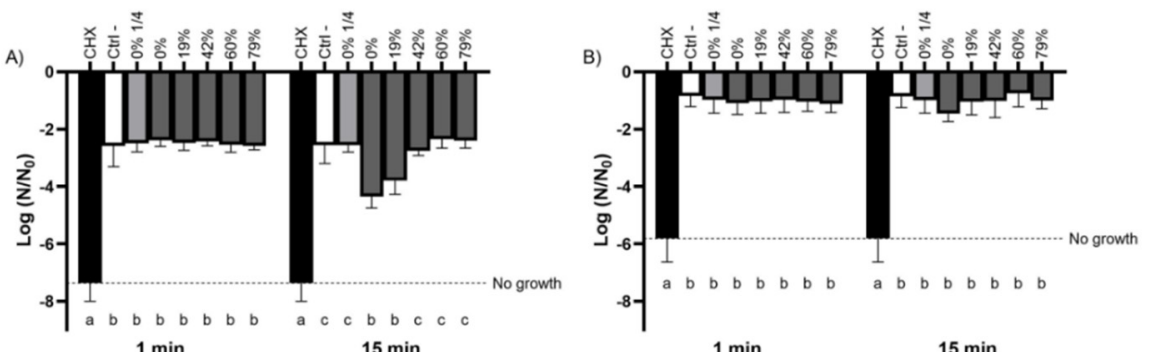

$1 \mathrm{~min}$

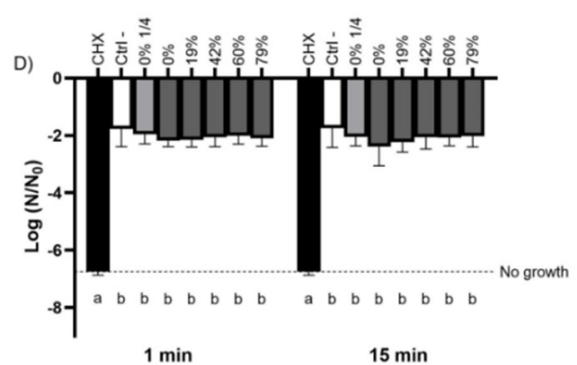

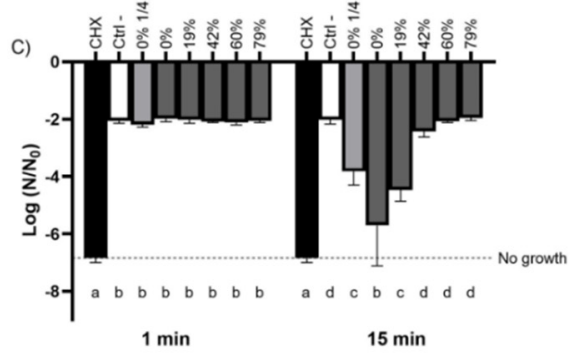

$15 \mathrm{~min}$

$1 \mathrm{~min}$

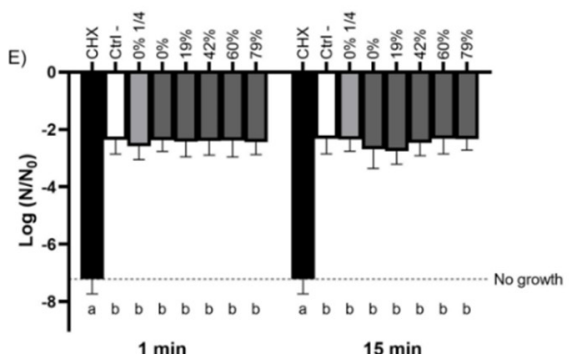

Figure 1. Effect of the deacidification rate $(0,19,42,60$, and $79 \%)$ of cranberry juice on the viability of planktonic oral streptococci reported as $\log$ of the initial bacterial count $\left(\mathrm{N}_{0}\right)$ following 1-min and 15-min contacts. The effect of a $\frac{1}{4}$ dilution of raw CJ on bactericidal activity was also studied. (A) S. mutans, (B) S. sobrinus, (C) S. gordonii, (D) S. oralis, and (E) S. salivarius. Results are expressed as mean $\log \left(\mathrm{N} / \mathrm{N}_{0}\right) \pm \mathrm{SD}$ of triplicate assays from two independent experiments. Columns with different letters are significantly different from one another (Two-way ANOVA, Bonferroni test, $p<0.01$ ). CHX: Chlorhexidine $0.12 \%$. Ctrl: Dilution buffer.

\subsection{Bactericidal Activity of the Raw and Deacidified CJs against Biofilm-Embedded Bacteria}

The extent to which the removal of organic acids from CJ impacts its bactericidal activity was further investigated using oral streptococci embedded in a biofilm (Figure 2). It required $15 \mathrm{~min}$ for undiluted raw $\mathrm{CJ}$ to significantly affect the viability of a S. mutans biofilm, lowering its viability rate to $74.3 \pm 3.0 \%$. On the other hand, DRs $\geq 19 \%$ suppressed this effect as did a $1 / 4$ dilution of raw $\mathrm{CJ}$ (Figure 2A). Although significant differences were obtained between DRs for biofilm-embedded S. sobrinus after $1 \mathrm{~min}$, viability rates were above $91 \%$ for all the CJ samples and even CHX, which indicated that biofilm-embedded S. sobrinus is resistant over the very short term (Figure 2B). However, the sensitivity of $S$. sobrinus biofilms to $C J$ increased with an extended exposure time, with viability rates dropping to $75.2 \pm 3.4 \%$ for undiluted raw CJ and $87.5 \pm 6.2 \%$ for the $19 \%$ DR CJ. The viability rates remained similar to that of PBS for DRs $\geq 42 \%$ after a contact time of $15 \mathrm{~min}$. The bactericidal activity of raw and 19\% DR CJs against biofilm-embedded S. gordonii manifested quickly, as shown by the significant loss in relative viability after $1 \mathrm{~min}$ (Figure 2C). However, the linear relationship between higher DRs and the viability 
rates of biofilm-embedded S. gordonii was more marked after a 15 min exposure. The viability rates for different DRs fell to $55.7 \pm 2.7 \%$ (undiluted raw $\mathrm{CJ}$ ), $64.3 \pm 8.0 \%(19 \%$ CJ), $70.3 \pm 8.8 \%(42 \% \mathrm{CJ}), 83.2 \pm 7.5 \%(60 \% \mathrm{CJ})$, and $95.0 \pm 2.0 \%(79 \% \mathrm{CJ})$, the effect of $79 \%$ CJ being statistically similar to the negative control. In addition, the calculated viability rate for the $1 / 4$ dilution of raw $\mathrm{CJ}(67.4 \pm 6.4 \%)$ was comparable to that of $19 \% \mathrm{CJ}$. Lastly, as was observed with planktonic bacteria, the viability of biofilm-embedded S. oralis and S. salivarius was not affected regardless of the DR, although CHX did significantly decrease their viability (Figure 2D,E). Overall, our results suggest that the raw and deacidified CJ samples exhibited antibacterial activities that were species-specific. In all cases, however, the viability of all the biofilm-embedded streptococcal species tested was more affected by $\mathrm{CHX}$ than by the CJ samples.

A)

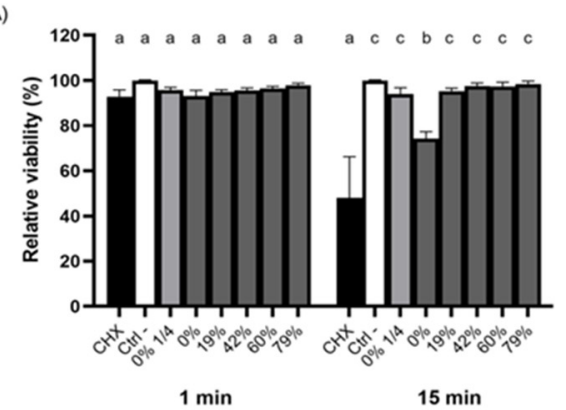

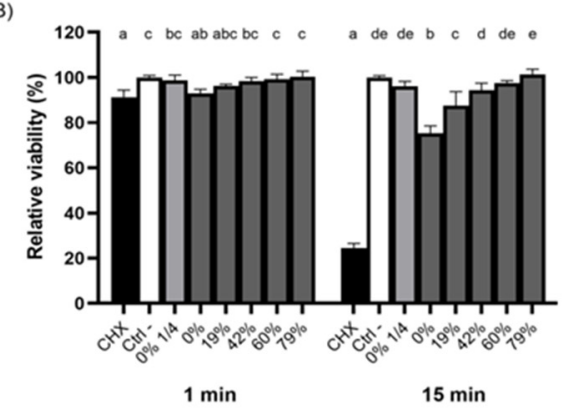

C)

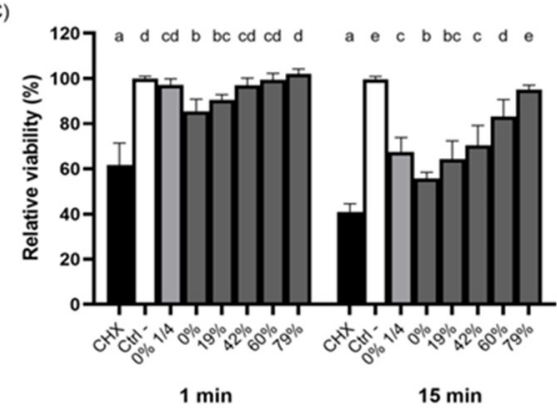

D)

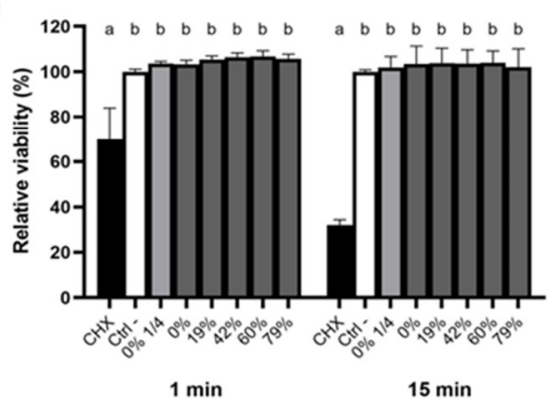

E)

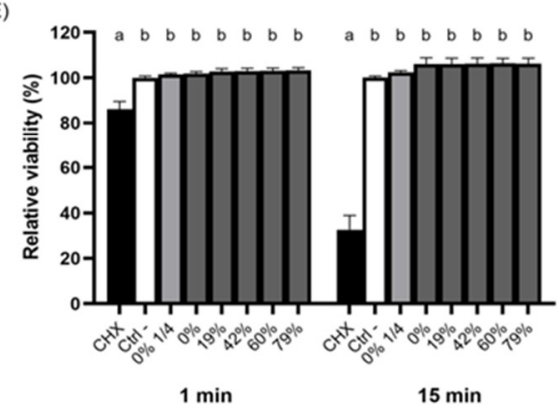

Figure 2. Effect of the deacidification rate $(0,19,42,60$, and $79 \%)$ of cranberry juice on the killing of biofilm-embedded (A) S. mutans, (B) S. sobrinus, (C) S. gordonii, (D) S. oralis, and (E) S. salivarius following 1- and 15-min exposures. A $\frac{1}{4}$ dilution of raw CJ was also included. Cell viability was assessed using FilmTracer LIVE/DEAD Biofilm Viability kit. A $100 \%$ value was attributed to the negative control (PBS). Results are expressed as means \pm SD of triplicate assays from three independent experiments. Columns with different letters are significantly different from one another (Two-way ANOVA, Bonferroni test, $p<0.01)$. CHX: Chlorhexidine 0.12\%. Ctrl: PBS.

\subsection{Impact of CJ Deacidification on Bacterial Adherence to Saliva-Coated HA}

Given that the formation of dental plaque and the process of dental caries rely on bacterial colonization of oral surfaces, we investigated the ability of raw and deacidified CJ samples to hinder bacterial adherence to HA, the primary mineral of dental enamel. Pre-conditioning saliva-coated HA with undiluted CJ samples hindered the adherence of S. mutans, regardless of the DR (Figure 3A), with the average fluorescence units measured being 1.5- to 1.9-times lower than the negative control (PBS, $\mathrm{pH} 7.2$ ) following a $1 \mathrm{~h}$ incubation. No significant differences were observed between CJ samples. The $1 / 4$ dilution of raw CJ led to a relative adherence of $79.4 \pm 6.1 \%$ compared to $60.6 \pm 20 \%$ for undiluted raw CJ. Overall, this shows that the phenolic compounds in the CJ samples, whose concentration remained the same in the undiluted CJ samples throughout the EDBM process (Table 1), were likely responsible for the decrease in adherence observed for $S$. mutans. A comparison with the results obtained for PBS at $\mathrm{pH}$ 2.6, which were not significantly different from the control (PBS at $\mathrm{pH}$ 7.2), supports this hypothesis. Similar results were obtained for S. sobrinus (Figure 3B) and S. oralis (Figure 3D), although, for S. oralis, the low $\mathrm{pH}$ of the CJ 
samples may have contributed, in part, to the reduction in bacterial adherence given that a significant decrease was observed for PBS at $\mathrm{pH} 2.6$ (33\% lower fluorescence) compared to PBS at pH 7.2. S. gordonii adhered to HA surfaces to the same extent for all the CJ samples and controls (Figure $3 \mathrm{C}$ ), which suggests that the cranberry phenolic compounds did not impair the adherence of this bacterial species. Interestingly, unlike the other streptococci tested, the adherence of $S$. salivarius to saliva-coated HA significantly increased following the conditioning of the HA surfaces with undiluted raw, 19\% DR or $42 \%$ DR CJs (Figure 3E). Indeed, the measured fluorescence for these three CJ samples was 1.4- to 1.6-times higher than for PBS ( $\mathrm{pH}$ 7.2). The low $\mathrm{pH}$ of the CJ samples did not appear to play a role in adherence to HA surfaces based on the relative fluorescence obtained with PBS at $\mathrm{pH} 2.6$.

A)

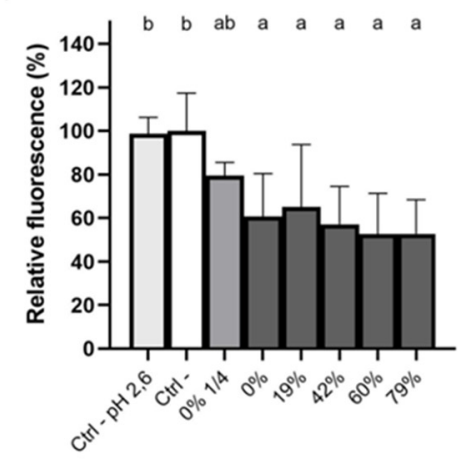

D)

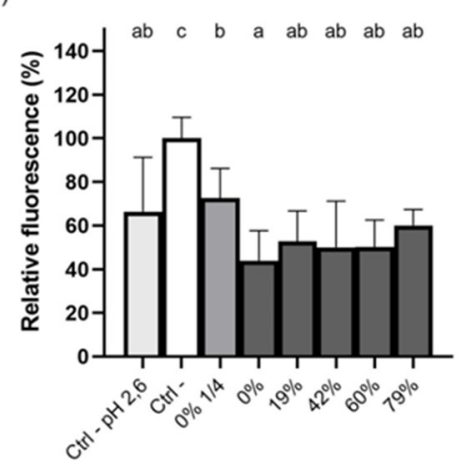

B)

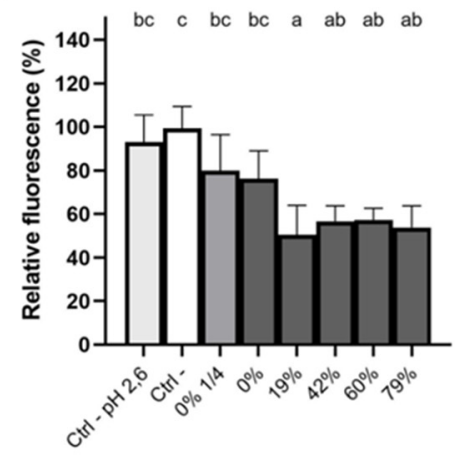

C)

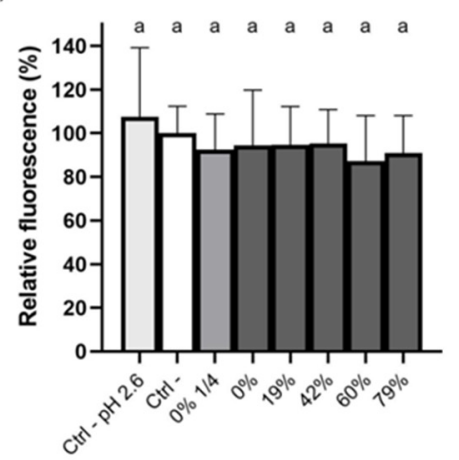

E)

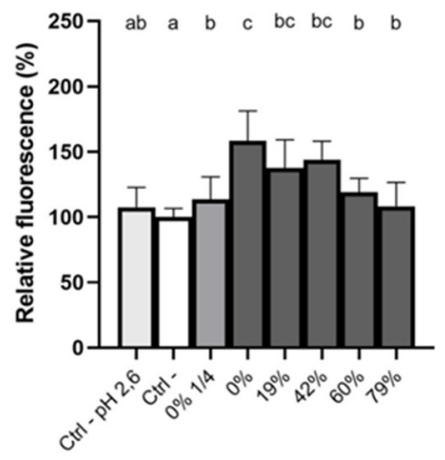

Figure 3. Adherence of FITC-labelled (A) S. mutans, (B) S. sobrinus, (C) S. gordonii, (D) S. oralis, and (E) S. salivarius to saliva-coated HA preconditioned (5 min) with raw or deacidified $(0,19,42,60$, and $79 \%$ ) cranberry juice. A $100 \%$ value was attributed to the negative control. Results are expressed as means $\pm \mathrm{SD}$ of triplicate assays from three independent experiments. Columns with different letters are significantly different from one another (ANOVA, Bonferroni test, $p<0.01$ ). Ctrl: PBS.

\subsection{Effect of CJ Deacidification on Oral Epithelial Barrier Integrity}

The oral epithelial mucosa is directly exposed to food and drink. It is thus of particular importance to determine whether the deacidification of $\mathrm{CJ}$ can help preserve the integrity of the oral epithelial barrier. A correlation between higher DRs and the maintenance of TER was observed shortly after a 5-min exposure to undiluted CJs (1-2 h follow-up) (Figure 4). Undiluted raw CJ reduced the relative TER to $33.4 \pm 0.4 \% 1 \mathrm{~h}$ post-exposure, whereas TER dropped to $56.7 \pm 0.8 \%$ with a $19 \%$ DR CJ. A DR $79 \%$ CJ had a protective effect over the short term, with the relative TER reaching $111.4 \pm 4.0 \% 1 \mathrm{~h}$ post-exposure and $104.5 \pm 3.6 \% 2 \mathrm{~h}$ post-exposure. These values were significantly higher than the control values in both cases. After a $6 \mathrm{~h}$ exposure to the CJ samples, the relative TER following exposure to raw $\mathrm{CJ}$ remained below that of all the deacidified CJ samples. The TER following exposure to the $79 \%$ DR CJ was higher than that of the other undiluted samples. No significant differences were observed for the $19 \%, 42 \%$, and $60 \%$ DR CJ samples. Nonetheless, the 
tight junction integrity of oral keratinocytes treated with the undiluted CJ samples did not recover after $24 \mathrm{~h}$, with the relative TER ranging from 21 to $47 \%$. However, the barrier function strengthened within $2 \mathrm{~h}$ following exposure to a $1 / 4$ dilution of raw $\mathrm{CJ}$, and the TER reached $138.6 \pm 5.2 \%$ of its initial value after $24 \mathrm{~h}$. The barrier integrity of the keratinocytes treated with growth medium (control) was restored after $24 \mathrm{~h}$ (relative TER of $96.3 \pm 7.2 \%)$.

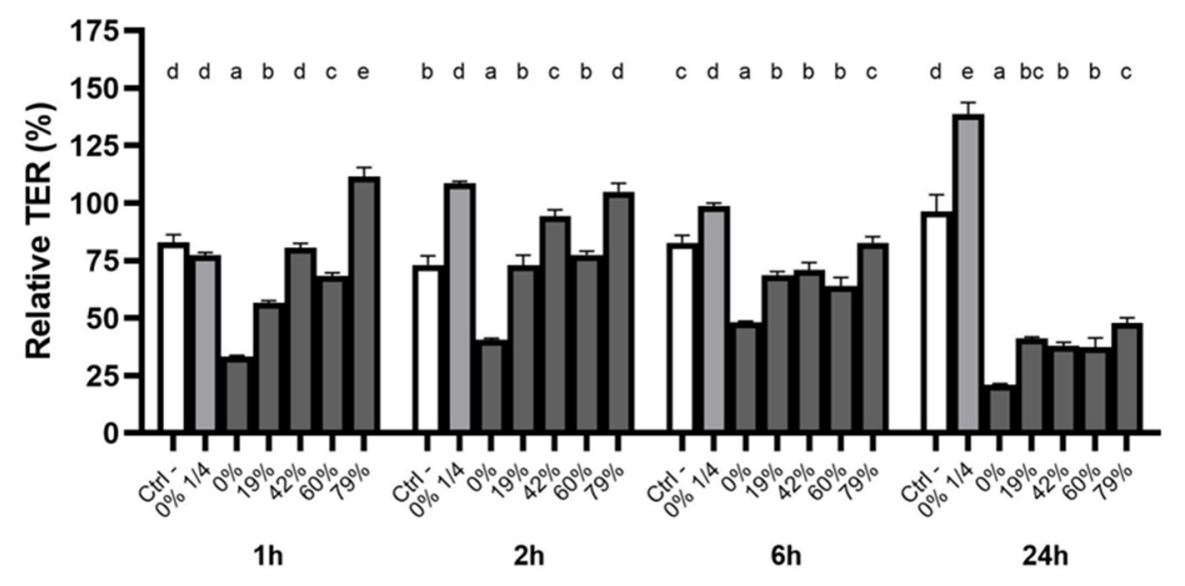

Figure 4. Time-dependent relative TER measurements of a B11 keratinocyte monolayer exposed ( $5 \mathrm{~min}$ ) to raw or deacidified $(0,19,42,60$, and $79 \%$ ) cranberry juice. The basal TER of each well was measured before the exposure to cranberry juice $\left(t_{0}\right)$. The results are expressed as means $\pm \mathrm{SD}$ of $\%$ of TER at $t_{0}$ ( $n=3$ from a representative experiment). Columns with different letters are significantly different from one another (Two-way ANOVA, Bonferroni test, $p<0.01$ ). Ctrl: antibiotic-free K-SFM.

\subsection{Impact of CJ Deacidification on the Paracellular Transport of FD-4}

The modulation of the integrity of the oral epithelial barrier by the deacidification of CJ was further investigated by monitoring the paracellular transport of FD-4 after a 5-min exposure to the CJ samples (Figure 5). The reduction in the permeability of the keratinocyte monolayer caused by deacidified CJ samples was correlated with the increase in DR. However, significant differences among CJ samples were only noted $24 \mathrm{~h}$ postexposure. Although the permeability of the keratinocyte barrier exposed to the 79\% DR CJ did not significantly differ from the control treatment, all other DRs caused an increase in permeability. Undiluted raw CJ led to an average FD-4 transport that was 3.1-times higher than that of the control, while a $1 / 4$ dilution of raw CJ had an effect on barrier integrity similar to that of the control. The results of FD-4 paracellular transport, together with the results of the TER measurements, suggest that organic acids could weaken the oral epithelial barrier and that this deleterious effect was lessened by CJ deacidification.

\subsection{Immunofluorescence Staining of ZO-1 and Occludin Following Exposure to CJ Samples}

To determine whether the disruption of epithelial barrier integrity was due to a modification in tight junction protein distribution, ZO-1 and occludin were immunostained $24 \mathrm{~h}$ after exposure to raw and deacidified CJ samples. As shown in Figure 6A, a brief 5-min contact with undiluted raw CJ had a mild effect on ZO-1 labeling. Slight discontinuities in paracellular ZO-1 were observed with this sample, as indicated by the arrows. Moreover, cell morphology was altered following the contact with the undiluted CJ samples, and treated keratinocytes appeared enlarged compared to the control cells. However, a more apparent impact on occludin distribution was observed with keratinocytes treated with undiluted raw CJ (Figure 6B). Discontinuities in the labeling of occludin and visible change in cell morphology were observed following exposure to undiluted raw CJ sample in comparison to the control. 


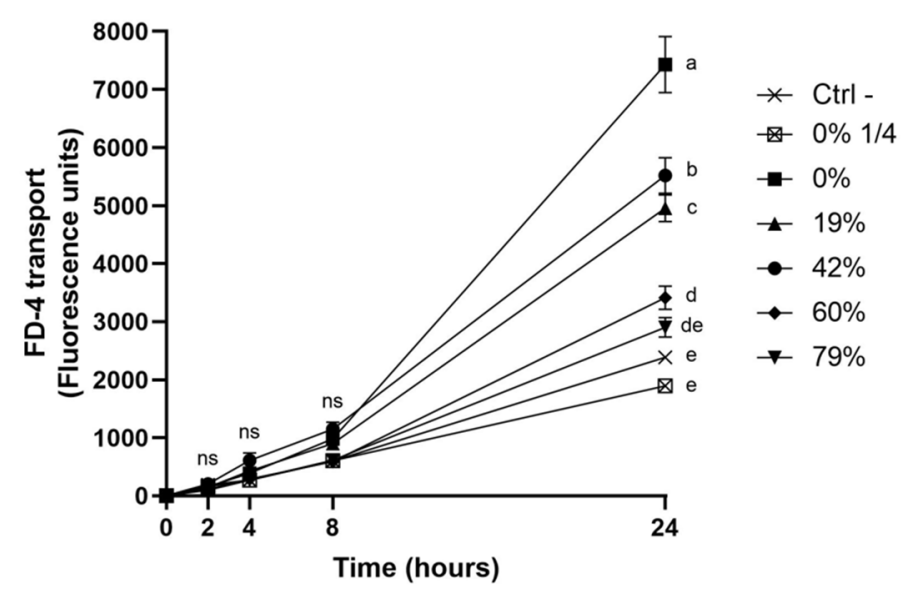

Figure 5. Time-dependent paracellular transport of FD-4 across a B11 keratinocyte monolayer exposed (5 $\mathrm{min})$ to raw or deacidified $(0,19,42,60$, and $79 \%$ ) cranberry juice. FD-4 was added to the apical compartment, and the fluorescence of the basolateral compartment is reported. Results are expressed as means \pm SD of triplicate assays from a representative experiment. Treatments with different letters are significantly different from one another (Two-way ANOVA, Bonferroni test, $p<0.01)$.

A)

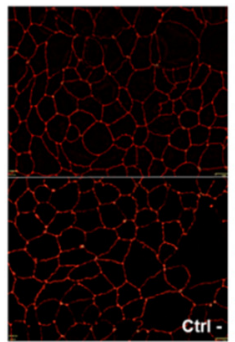

B)

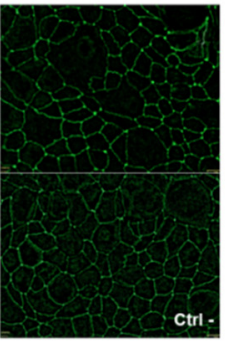

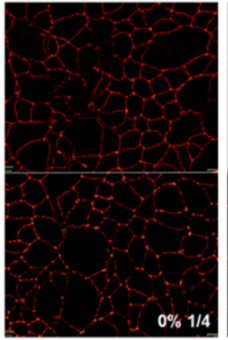

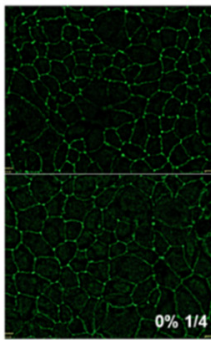

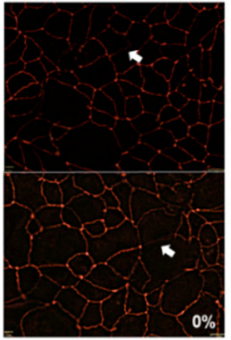

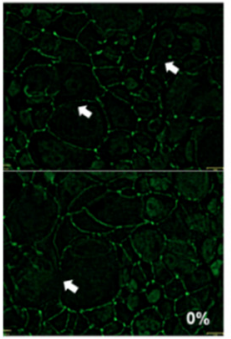

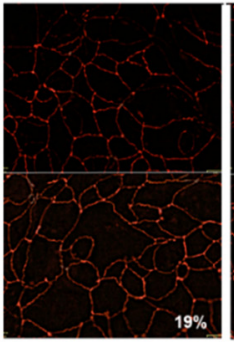

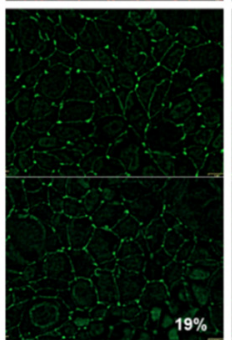

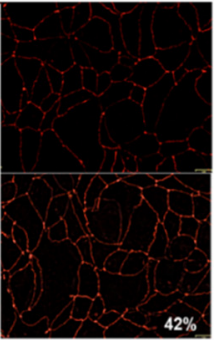

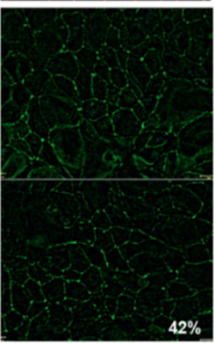

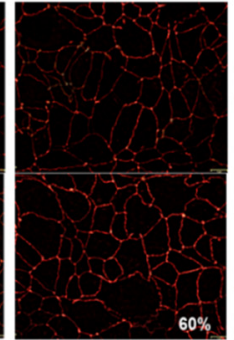
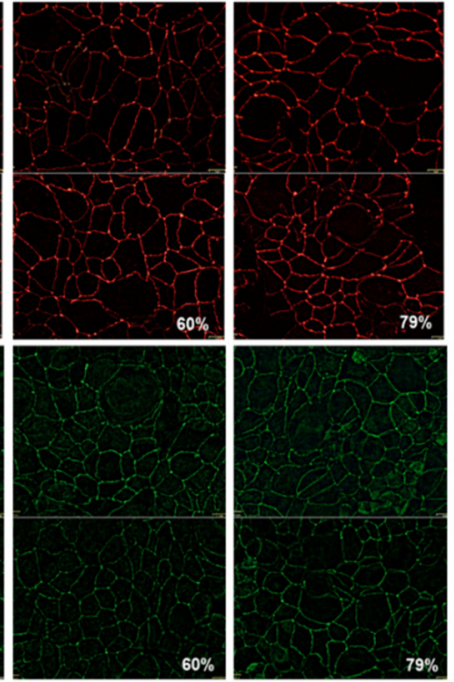

Figure 6. Immunofluorescence staining of (A) zonula occludens-1 (ZO-1) and (B) occludin in B11 oral keratinocytes $24 \mathrm{~h}$ after being challenged by raw or deacidified $(0,19,42,60$, and $79 \%)$ cranberry juice for 5 min. Images from two independent experiments are presented.

\subsection{Effect of CJ Deacidification on IL-6 and IL-8 Production by Oral Epithelial Cells}

The production of the pro-inflammatory cytokines IL- 6 and IL-8 by oral epithelial cells treated with CJ samples was investigated using the GMSM-K cell line (Figure 7). All the raw and deacidified CJ samples caused an increase in the production of IL-6 by epithelial cells compared to the negative control (DMEM + 1\% FBS) (Figure 7A), which could be partly explained by the low $\mathrm{pH}$ of the samples. Indeed, epithelial cells subjected to a sample of growth medium whose $\mathrm{pH}$ has been adjusted to 2.6 with $\mathrm{HCl}$ produced more IL-6 than the negative control (neutral pH). Additionally, CJ samples with DRs $\geq 19 \%$ were more inflammatory than undiluted and diluted raw CJ samples. However, there was a significant decrease in IL-6 secretion when the DR reached 79\%, compared to $60 \%$ DR. The production of IL- 8 by oral epithelial cells treated with the CJ samples was not significantly affected by the DR, although an increase in production was observed 
at higher DRs (Figure 7B). Moreover, the raw and 19\% DR CJ samples had no effect on the production of this chemokine compared to the negative control. The low $\mathrm{pH}$ of $\mathrm{CJ}$ was not a triggering factor in the secretion of IL- 8 by oral epithelial cells as there was no significant difference in IL-8 concentrations between the neutral $\mathrm{pH}$ growth medium and the $\mathrm{pH}$-adjusted growth medium ( $\mathrm{pH}$ 2.6).

A)

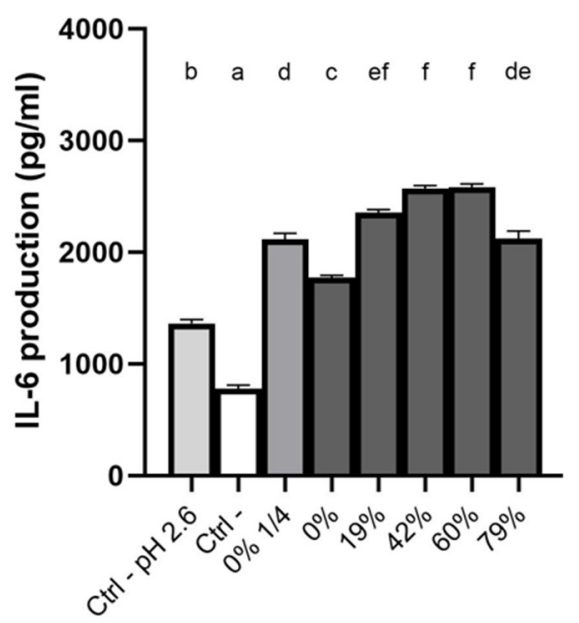

B)

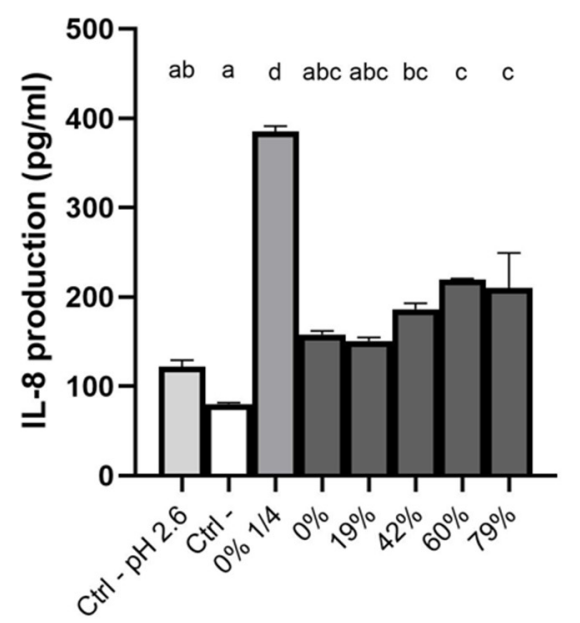

Figure 7. Effect on the production of (A) IL-6 and (B) IL-8 of a 5-min exposure of GMSM-K oral epithelial cells to raw or deacidified $(0,19,42,60$, and $79 \%)$ cranberry juice. A $\frac{1}{4}$ dilution of raw CJ was also included. Cells were incubated for $24 \mathrm{~h}$ post-exposure, following which the supernatants were collected and the secretion of cytokines was measured. Results are expressed as means \pm SD of a triplicate assay. Columns with different letters are significantly different from one another (ANOVA, Bonferroni test, $p<0.01$ ). Ctrl: DMEM $+1 \%$ FBS.

\section{Discussion}

\subsection{Bactericidal Activity of Raw and Deacidified CJs against Planktonic and} Biofilm-Embedded Streptococci

A study by Svensäter et al. [44] showed that a $\mathrm{pH}$ between 3.0 and 3.5 kills the streptococci tested in the present study. However, the raw and deacidified CJ samples, with pHs ranging from 2.6 to 3.2 (Table 1), did not cause the complete eradication of the planktonic bacteria. The high sugar content of the undiluted CJ samples at all DRs (average of $46.9 \pm 6.5 \mathrm{~g} / \mathrm{L}$ of glucose equivalents) may have provided some protection to the bacteria. Indeed, Sheng and Marquis [45] reported that a $5 \mathrm{~g} / \mathrm{L}$ concentration of glucose can attenuate the death of oral streptococci under acidic stress (at pH 3.0 for S. mutans and S. sobrinus, and $\mathrm{pH} 3.5$ for S. gordonii). A second factor that may have protected the bacteria from the acidic effect of the CJ samples is the ability of mutans streptococci to mount an acid tolerance response (ATR), which allows them to maintain an active metabolism under sub-lethal $\mathrm{pH}$ conditions [46,47]. Mutans streptococci can mount an ATR when they are grown in glucose-enriched medium, which promotes the production of glucans [48]. The BHI broth medium was supplemented with $0.5 \%$ glucose, which would thus have further increased the aciduricity of the bacteria.

The present study revealed that there is a significant reduction in planktonic bacterial populations of $S$. mutans exposed for $15 \mathrm{~min}$ to undiluted raw and 19\% DR CJs. Although S. mutans is an acid-tolerant bacteria, citrate $(1.5 \mathrm{~g} / \mathrm{L})$ has been reported to enhance the killing of planktonic $S$. mutans, especially at low $\mathrm{pH}$ values $[49,50]$. Furthermore, the ATR of $S$. mutans is characterized by an increase in $\mathrm{F}_{1} \mathrm{~F}_{0}$-ATPase activity, which helps maintain an internal $\mathrm{pH} 0.5$ to 1.0 unit more alkaline than the external $\mathrm{pH}[46,47,51]$. However, Duarte et al. [18] showed that a cranberry extract $(20 \mathrm{mg} / \mathrm{mL})$ containing $300-500 \mu \mathrm{g} / \mathrm{mL}$ of PACs inhibits the ATPase activity of $S$. mutans by $80 \%$, whereas Gregoire et al. [19] reported that cranberry flavonoids $(500 \mu \mathrm{M})$, taken individually and in combination, cause 
an $18-33 \%$ reduction in F-ATPase activity. Given this, the phenolic content of CJ may have impaired the protective mechanisms inherent to $S$. mutans, which may have led to the fast decrease in bacterial populations at low DRs.

In the case of $S$. sobrinus, planktonic bacterial cells survived 1-min and 15-min exposures to all the CJ samples, which contradicts the work of Kranz et al. [52], who reported that a 1-min immersion in undiluted CJ completely eliminates this bacterium. This discrepancy may be explained by the different growth media used. Nascimento et al. [53] suggested that $S$. sobrinus can mount an ATR by increasing the activity of the glucose phosphoenolpyruvate:sugar phosphotransferase system (PTS) when grown in a $\mathrm{pH}$ environment. The Tryptone Soy Broth used by Kranz et al. [52] was not enriched in glucose, unlike the BHI used in the present study, which was supplemented with $0.5 \%$ glucose. The lack of glucose enrichment may have prevented the production of large amounts of acids by glycolysis during the growth of the bacterium, and may thus have prevented $S$. sobrinus from mounting an ATR that could have protected it during the exposure to CJ. S. sobrinus also relies on an increase in malolactic fermentation to protect itself in low $\mathrm{pH}$ environments [53,54]. It should be noted here that the CJ samples contained L-malate when the DR was $\leq 60 \%$. It has also been reported that the F-ATPase activity of $S$. sobrinus remains stable or increases slightly under acidic stress [53,54], meaning that phenolic compounds in CJ do not hinder its ability to survive the 15-min exposure, regardless of the DR. No bactericidal activity of CJ diluted to $1 / 4$ against planktonic $S$. mutans and $S$. sobrinus has been reported in the literature [20,52].

Svensäter et al. [44] reported that $S$. gordonii is the least acid-tolerant streptococcus, which corroborates the results obtained with the streptococci tested in the present study. The survival of planktonic S. oralis and S. salivarius that we observed suggests that they could survive in an acidic environment, at least over the short term. This could be linked to the activity of the arginine deiminase system (ADS), which increases the resistance of the bacteria at pH 3.5 [55-57].

All the streptococci tested possess one or more genes encoding GTFs [11], which enables them to produce an EPS matrix using the glucose in the growth medium [58]. The biofilm-embedment of streptococci in an EPS matrix is crucial as it slows down the diffusion of charged or high molecular weight compounds such as protons $\left(\mathrm{H}^{+}\right)$and anionic forms of organic acids, and creates stable microenvironments in the form of microcolonies [12]. Hwang et al. [12] subjected a preformed $S$. mutans biofilm to matrix degradation using dextranase and showed that the $\mathrm{pH}$ of the $S$. mutans biofilms, which was highly acidic prior to the degradation of the EPS, is neutralized after a 60 -min exposure to $\mathrm{Na}_{2} \mathrm{HPO}_{4}$-citric acid buffer ( $\mathrm{pH} 7$ ), whereas the $\mathrm{pH}$ increases only in the top layer of the biofilm in the presence of a neutral buffer when the EPS was left intact [12]. It may thus be possible that the decrease in biofilm viability observed for $S$. mutans and S. sobrinus following a 15-min exposure to undiluted raw CJ affected the upper layer more than the bottom layer of the biofilms [12,59]. A study by Gilmore et al. [58] showed that an early-formed S. gordonii biofilm (<4 days) lacks a complex structure and bacterial clusters. Consequently, the viability rates of $24 \mathrm{~h} \mathrm{~S}$. gordonii biofilms exposed to CJ samples, which decreased linearly with the increase in DR, may be the result of a rather loose EPS matrix that does not substantially hinder the diffusion of the organic acids in the CJ [60,61]. On the other hand, EPS-embedded microcolonies have been observed by confocal microscopy in $24 \mathrm{~h} \mathrm{~S}$. oralis biofilms [62]. This type of biofilm structure may explain why the viability of $S$. oralis was not affected by the CJ treatments.

\subsection{Effect of CJ Deacidification on the Adherence of Streptococci to Saliva-Coated HA}

Plant polyphenols found in various beverages reduce the adherence of mutans streptococci to enamel either in vitro or in situ upon consumption [20,63]. Koo et al. [20] observed a 6.2-fold decrease in the adherence of $S$. mutans to salivary-coated HA preconditioned with a 1/4 diluted CJ compared to pretreatment with a control devoid of phenolic compounds and containing only CJ sugars and organic acids. Interestingly, a 30-min pretreatment of 
bacterial suspensions with a $\mathrm{CJ}$ whose $\mathrm{pH}$ had been adjusted to 5.5 does not hamper the attachment of S. mutans to HA beads [20]. This suggests that the phenolic compounds in CJ hinder bacterial adherence through interactions with salivary proteins more than with bacterial cell surface proteins. Weiss et al. [64] reported that non-dialyzable CJ material has a similar effect on the adherence of $S$. sobrinus to HA. The results of the present study indicate that a $1 / 4$ dilution of raw $C J$ increased the attachment of $S$. mutans and S. sobrinus to HA compared to undiluted CJs, further reflecting the role that cranberry polyphenols play in the anti-adherence properties of the beverage. The adherence of mitis streptococci such as S. gordonii and S. oralis mainly relies on binding to sialic acid and salivary glycoproteins such as mucins $[2,65,66]$. These early colonizers possess diverse lectins and use various mechanisms to adhere to HA $[2-4,67,68]$. The CJ samples could have affected bacterial colonization of HA surfaces in a species-specific way, which would explain the differences observed with the adherence of commensal streptococci to HA. The increase in the adherence of $S$. salivarius to saliva-coated HA may be more linked to its ability to auto-aggregate than to an enhancement of bacterial adherence driven by CJ [69].

\subsection{Effect of CJ Deacidification on Oral Epithelial Barrier Function}

The maintenance of the integrity of the oral mucosa is key to avoid bacterial invasion of the underlying connective tissue. The results from the present study show that deacidification of CJ protected tight junction integrity in an oral keratinocyte model shortly after contact with the beverage as determined by the analyses of TER and the paracellular transport of FD-4. Serre et al. [30] proposed that a minimum DR of $37 \%$ is required to improve the maintenance of intestinal barrier integrity in vitro compared to non-deacidified CJ. The results from the present study suggest that a DR of $19 \%$ was sufficient to have a beneficial impact on the oral keratinocyte barrier. However, the batch of raw CJ used by Serre et al. [30] contained higher concentrations of citric acid (1.9 times more) and malic acid (2.3 times more) than the CJ we used in the present study, which may justify the need for a higher DR. Furthermore, Renaud et al. [31], who investigated how the type of organic acid removed from CJ impacts the TER of a Caco-2 intestinal cell monolayer, provided evidence that citrate contributes to the disruption of the epithelial barrier more than malate. Okada et al. [70] showed that the permeability of the vaginal epithelium of rats treated with acidic solutions for $1 \mathrm{~h}$ is enhanced by solutions with a lower $\mathrm{pH}$ (3.5 instead of 6.6), higher concentrations of organic acid, and the stronger chelating ability of the acid they contain (citrate $>$ malate). This could be attributed to the presence of three binding sites on the molecular structure of citrate, as opposed to two for malate, which means that citrate binds more calcium ions than malate [71]. As $\mathrm{Ca}^{2+}$ is essential for localizing tight junction proteins such as ZO-1 and occludin at cell-cell contact sites [72], this means that the citrate in CJ can damage the integrity of the epithelial barrier. The beneficial impact of CJ deacidification on tight junction integrity observed for the first $6 \mathrm{~h}$ following exposure probably relies on the selective removal of up to $80 \%$ of the citrate from CJ by EDBM.

Okada et al. [70] showed that the integrity of the rat vaginal epithelial barrier recovers $2 \mathrm{~h}$ after exposure. This contradicts our results with the oral keratinocyte model showing the inability of oral keratinocytes to recover from the acidic stress caused by the $\mathrm{CJ}$ samples even after $24 \mathrm{~h}$. This was likely due to the high sugar content of the undiluted CJ samples (Table 1), which could also explain the change in cell morphology that was observed. Yu et al. [73] treated Caco-2 intestinal epithelial cells at confluence with a high concentration of glucose $(135 \mathrm{~g} / \mathrm{L})$ for $60 \mathrm{~min}$, and reported that the permeability of the epithelial barrier to FITC-conjugated $70 \mathrm{kDa}$ dextran increases two-fold compared to the control. A decrease in epithelial barrier integrity caused by glucose $(3.6 \mathrm{~g} / \mathrm{L})$ through a reduction in TER has also been reported by Mongelli-Sabino et al. [74] for the MDCK kidney epithelial cell line. Moreover, the maintenance of the epithelial barrier integrity following the treatment with $1 / 4$ diluted raw $\mathrm{CJ}$ at all the times tested, compared to undiluted $\mathrm{CJ}$ samples, may have been caused by the lower glucose content resulting from the dilution of the raw $\mathrm{CJ}$ with distilled water. It is noteworthy that Yu et al. [73] associated the noticeable swelling 
of Caco-2 cells they observed with the activation of the $\mathrm{Na}^{+} /$glucose cotransporter by a glucose solution $(135 \mathrm{~g} / \mathrm{L})$. This cotransporter may also be involved in glucose absorption by human oral mucosa ex vivo following a 5-min exposure to glucose [75], indicating that the change in keratinocyte morphology observed by immunostaining may be caused by the glucose content of undiluted CJ.

However, it should be mentioned that our results were obtained in a static oral epithelial barrier model devoid of salivary glands, which is not representative of the complex physiological response that occurs following gustatory stimulation with food and beverages. Studies comparing static and dynamic in vitro models of the intestinal barrier and the blood-brain barrier showed that the constant flow of growth medium in dynamic models preserved the integrity and reduced the permeability of the barriers $[76,77]$. Based on these studies, and especially considering that acids contained in food greatly stimulate the salivary flow in the oral cavity [78], it is likely that the reported impact of CJ deacidification on the oral barrier integrity would not be as significant following human consumption of the juice. Further experiments are required to confirm the benefits of $\mathrm{CJ}$ deacidification on the oral mucosa in vivo.

\subsection{Effect of CJ Deacidification on the Production of IL-6 and IL-8 by Oral Epithelial Cells}

A 5-min contact with raw and deacidified CJs induced a significantly higher secretion of IL-6 by oral epithelial cells compared to the negative control. Based on reports in the literature, the organic acid composition and sugar content of CJ may modulate the overproduction of this pro-inflammatory cytokine. Held et al. [79] showed that a $6 \mathrm{~h}$ exposure to orange juice diluted 1:10 induces $22 \%$ higher IL- 6 production by KB epithelial cells than untreated cells and that approximately half of the increase is due to the organic acid content (as with CJ, orange juice is rich in CA and MA), while the other half is related to the sugar fraction of the orange juice. Interestingly, they reported that there is no increase in the inflammatory response when the KB cells are treated with growth medium with a $\mathrm{pH}$ of 4.2. However, we showed that GMSM-K epithelial cells produce more IL-6 when exposed to DMEM at $\mathrm{pH} 2.6$ than to the neutral control. This discrepancy may be caused by differences in cell lines and in $\mathrm{pH}$ values. In addition, epithelial cells are hypertonically stressed by the carbohydrates in CJ. For instance, a $2 \mathrm{~h}$ treatment of Caco-2 intestinal epithelial cells in a hyperosmotic environment causes an overexpression of the gene encoding IL-6 [80].

The deacidification of $\mathrm{CJ}$ also had an impact on the production of the pro-inflammatory chemokine IL-8. The significant differences observed between the negative control and all the CJ samples with different DRs may have been caused by the osmolarity of the CJ samples. Grauso et al. [80] used hyperosmotic solutions of mannitol ( $30 \mathrm{~g} / \mathrm{L}$ and $60 \mathrm{~g} / \mathrm{L})$ to investigate how osmotic pressure impacts the intestinal barrier in vitro. They reported that, compared to an isotonic control, the expression of the CXCL8 gene in Caco-2 cells increases 14.2-fold and 4.8-fold when the cells are exposed for $2 \mathrm{~h}$ to the $30 \mathrm{~g} / \mathrm{L}$ mannitol solution and the $60 \mathrm{~g} / \mathrm{L}$ mannitol solution, respectively [80]. This indicates that a lower hypertonic stress induces a higher production of IL-8, which is in accordance with our results with $1 / 4$ diluted CJ and undiluted CJs for GMSM-K cells. The results of Lan et al. [81], who measured a 1.5-times higher concentration of IL- 8 in the supernatant of keratinocytes exposed to $26 \mathrm{mM}(4.7 \mathrm{~g} / \mathrm{L})$ glucose for 7 days are in line with this explanation.

\section{Conclusions}

Overall, the deacidification process had little impact on the bactericidal activities of $\mathrm{CJ}$ against the five species of streptococci tested compared to the raw product. Apart from S. mutans (planktonic) and S. gordonii (planktonic and biofilm-embedded), bacterial viability was only slightly impacted by a 15 -min contact with the CJ samples, regardless of the organic acid profile. Furthermore, all the undiluted CJ samples reduced the adherence of the two cariogenic species tested to saliva-coated HA to an equal extent, while they did not impair the adherence of $S$. gordonii and S. salivarius. Although the $1 / 4$ dilution of raw 
CJ lowered the antibacterial properties of CJ against S. mutans and S. sobrinus, the change was not significant. We used an in vitro oral epithelium model to show that removing organic acids had a beneficial effect as it dampened the disruption of the epithelial barrier function induced by the raw CJ. This appeared to be related to the maintenance of tight junction protein integrity. When the raw $\mathrm{CJ}$ was diluted in water prior to consumption, as recommended by the manufacturer, it caused significantly less damage in the in vitro oral epithelium model due to the reduction in its glucose content. However, the dilution of the raw CJ caused a spike in IL-8 secretion by oral epithelial cells. Based on these results, the deacidification of $\mathrm{CJ}$ appears to be a promising compromise as it minimized the adherence of cariogenic species and maximized the maintenance of epithelial barrier integrity. Further studies using in vivo models are required to determine whether this conclusion holds true in the human oral cavity.

Author Contributions: Conceptualization, G.P., L.B. and D.G.; methodology, G.P.; software, G.P.; validation, G.P., L.B. and D.G.; formal analysis, G.P.; investigation, G.P., L.B. and D.G.; resources, G.P., L.B. and D.G.; data curation, G.P.; writing—original draft preparation, G.P.; writing—review and editing, G.P., L.B. and D.G.; visualization, G.P., L.B. and D.G.; supervision, L.B. and D.G.; project administration, L.B.; funding acquisition, L.B. and D.G. All authors have read and agreed to the published version of the manuscript.

Funding: This study was funded by Laboratoire de Contrôle microbiologique of Université Laval [2019-2020 to D. Grenier], the NSERC Industrial Research Chair on ElectroMembrane processes aiming improvement of the ecoefficiency of biofood production lines [IRCPJ 492889-15 to L. Bazinet], and Consortium de Recherche et Innovations en Bioprocédés Industriels au Québec [2017-072-C34 to L. Bazinet]. The Canada Graduate Scholarships-Master's program of the Natural Sciences and Engineering Research Council of Canada (NSERC) and by the Master's Research Scholarships of Fonds de recherche du Québec-Nature et technologies (FRQNT) are also acknowledged.

Institutional Review Board Statement: Not applicable.

Informed Consent Statement: Not applicable.

Data Availability Statement: Data is contained within the article.

Acknowledgments: The authors thank S. Groeger and J. Meyle (Department of Periodontology, Justus-Liebig-University Giessen, Germany) for providing the B11 keratinocyte cell line, and V. Murrah (University of North Carolina at Chapel Hill) for providing the GMSM-K epithelial cell line. The technical assistance of A. Ben Lagha and K. Vaillancourt is gratefully acknowledged.

Conflicts of Interest: The authors declare no conflict of interest.

\section{References}

1. Hojo, K.; Nagaoka, S.; Ohshima, T.; Maeda, N. Bacterial interactions in dental biofilm development. J. Dent. Res. 2009, 88, 982-990. [CrossRef]

2. Ligtenberg, A.J.; Walgreen-Weterings, E.; Veerman, E.C.; de Soet, J.J.; de Graaff, J.; Amerongen, A.V. Influence of saliva on aggregation and adherence of Streptococcus gordonii HG 222. Infect. Immun. 1992, 60, 3878-3884. [CrossRef] [PubMed]

3. Murray, P.A.; Prakobphol, A.; Lee, T.; Hoover, C.I.; Fisher, S.J. Adherence of oral streptococci to salivary glycoproteins. Infect. Immun. 1992, 60, 31-38. [CrossRef]

4. Kolenbrander, P.E.; Palmer, R.J.; Periasamy, S.; Jakubovics, N.S. Oral multispecies biofilm development and the key role of cell-cell distance. Nat. Rev. Microbiol. 2010, 8, 471-480. [CrossRef] [PubMed]

5. Nobbs, A.H.; Zhang, Y.; Khammanivong, A.; Herzberg, M.C. Streptococcus gordonii Hsa environmentally constrains competitive binding by Streptococcus sanguinis to saliva-coated hydroxyapatite. J. Bacteriol. 2007, 189, 3106-3114. [CrossRef]

6. Wang, S.-S.; Tang, Y.-L.; Pang, X.; Zheng, M.; Tang, Y.-J.; Liang, X. h. The maintenance of an oral epithelial barrier. Life Sci. 2019, 227, 129-136. [CrossRef]

7. Peterson, S.N.; Snesrud, E.; Liu, J.; Ong, A.C.; Kilian, M.; Schork, N.J.; Bretz, W. The dental plaque microbiome in health and disease. PLoS ONE 2013, 8, e58487. [CrossRef] [PubMed]

8. Seki, M.; Yamashita, Y.; Shibata, Y.; Torigoe, H.; Tsuda, H.; Maeno, M. Effect of mixed mutans streptococci colonization on caries development. Oral Microbiol. Immunol. 2006, 21, 47-52. [CrossRef] [PubMed]

9. Hirose, H.; Hirose, K.; Isogai, E.; Miura, H.; Ueda, I. Close association between Streptococcus sobrinus in the saliva of young children and smooth-surface caries increment. Caries Res. 1993, 27, 292-297. [CrossRef] 
10. Gross, E.L.; Beall, C.J.; Kutsch, S.R.; Firestone, N.D.; Leys, E.J.; Griffen, A.L. Beyond Streptococcus mutans: Dental caries onset linked to multiple species by $16 \mathrm{~S}$ rRNA community analysis. PLoS ONE 2012, 7, e47722. [CrossRef]

11. Banas, J.A.; Vickerman, M.M. Glucan-binding proteins of the oral streptococci. Crit Rev. Oral Biol. Med. 2003, 14, 89-99. [CrossRef]

12. Hwang, G.; Liu, Y.; Kim, D.; Sun, V.; Aviles-Reyes, A.; Kajfasz, J.K.; Lemos, J.A.; Koo, H. Simultaneous spatiotemporal mapping of in situ $\mathrm{pH}$ and bacterial activity within an intact 3D microcolony structure. Sci. Rep. 2016, 6, 1-11. [CrossRef] [PubMed]

13. Ministère de l'Agriculture des Pêcheries et de l'Alimentation du Québec (MAPAQ). Portrait-Diagnostic Sectoriel de la Canneberge au Québec; Gouvernement du Québec: Quebec City, PQ, Canada, 2018.

14. Feghali, K.; Feldman, M.; La, V.D.; Santos, J.; Grenier, D. Cranberry proanthocyanidins: Natural weapons against periodontal diseases. J. Agric. Food Chem. 2011, 60, 5728-5735. [CrossRef]

15. Rocha, D.M.U.P.; Caldas, A.P.S.; da Silva, B.P.; Hermsdorff, H.H.M.; Alfenas, R.D.C.G. Effects of blueberry and cranberry consumption on type 2 diabetes glycemic control: A systematic review. Crit. Rev. Food Sci. Nutr. 2019, 59, 1816-1828. [CrossRef] [PubMed]

16. Thimóteo, N.S.B.; Scavuzzi, B.M.; Simão, A.; Dichi, I. The impact of cranberry (Vaccinium macrocarpon) and cranberry products on each component of the metabolic syndrome: A review. Nutrire 2017, 42, 1-12. [CrossRef]

17. Weh, K.M.; Clarke, J.; Kresty, L.A. Cranberries and cancer : An update of preclinical studies evaluating the cancer inhibitory potential of cranberry and cranberry derived constituents. Antioxidants 2016, 5, 27. [CrossRef]

18. Duarte, S.; Gregoire, S.; Singh, A.P.; Vorsa, N.; Schaich, K.; Bowen, W.H.; Koo, H. Inhibitory effects of cranberry polyphenols on formation and acidogenicity of Streptococcus mutans biofilms. FEMS Microbiol. Lett. 2006, 257, 50-56. [CrossRef] [PubMed]

19. Gregoire, S.; Singh, A.P.; Vorsa, N.; Koo, H. Influence of cranberry phenolics on glucan synthesis by glucosyltransferases and Streptococcus mutans acidogenicity. J. Appl. Microbiol. 2007, 103, 1960-1968. [CrossRef] [PubMed]

20. Koo, H.; de Guzman, P.; Schobel, B.D.; Vacca Smith, A.V.; Bowen, W.H. Influence of cranberry juice on glucan-mediated processes involved in Streptococcus mutans biofilm development. Caries Res. 2006, 40, 20-27. [CrossRef]

21. Philip, N.; Bandara, H.M.H.N.; Leishman, S.J.; Walsh, L.J. Effect of polyphenol-rich cranberry extracts on cariogenic biofilm properties and microbial composition of polymicrobial biofilms. Archives 2019, 102, 1-6. [CrossRef] [PubMed]

22. Neto, C.C.; Penndorf, K.A.; Feldman, M.; Steinberg, D.; Fridman, M.; Kashman, Y.; Ginsburg, I.; Ofek, I.; Weiss, E.I. Characterization of non-dialyzable constituents from cranberry juice that inhibit adhesion, co-aggregation and biofilm formation by oral bacteria. Food Funct. 2017, 8, 1955-1965. [CrossRef]

23. Faucher, M.; Serre, E.; Langevin, M.-E.; Mikhaylin, S.; Lutin, F.; Bazinet, L. Drastic energy consumption reduction and ecoefficiency improvement of cranberry juice deacidification by electrodialysis with bipolar membranes at semi-industrial scale: Reuse of the recovery solution. J. Memb. Sci. 2018, 555, 105-114. [CrossRef]

24. Faucher, M.; Henaux, L.; Chaudron, C.; Mikhaylin, S.; Margni, M.; Bazinet, L. Electromembrane approach to substantially improve the ecoefficiency of deacidified cranberry juice production: Physicochemical properties, life cycle assessment and ecoefficiency score. J. Food Eng. 2020, 273, 109802. [CrossRef]

25. Serre, E.; Rozoy, E.; Pedneault, K.; Lacour, S.; Bazinet, L. Deacidification of cranberry juice by electrodialysis: Impact of membrane types and configurations on acid migration and juice physicochemical characteristics. Sep. Purif. Technol. 2016, 163, 228-237. [CrossRef]

26. Stapleton, A.E.; Dziura, J.; Hooton, T.M.; Cox, M.E.; Yarova-Yarovaya, Y.; Chen, S.; Gupta, K. Recurrent urinary tract infection and urinary Escherichia coli in women ingesting cranberry juice daily: A randomized controlled trial. Mayo Clin. Proc. 2012, 87, 143-150. [CrossRef]

27. Wing, D.A.; Rumney, P.J.; Preslicka, C.; Chung, J.H. Daily cranberry juice for the prevention of asymptomatic bacteriuria in pregnancy: A randomized, controlled pilot study. J. Urol. 2009, 180, 1367-1372. [CrossRef] [PubMed]

28. Lussi, A.; Megert, B.; Shellis, R.P.; Wang, X. Analysis of the erosive effect of different dietary substances and medications. Br. J. Nutr. 2012, 107, 252-262. [CrossRef] [PubMed]

29. Zheng, J.; Xiao, F.; Qian, L.M.; Zhou, Z.R. Erosion behavior of human tooth enamel in citric acid solution. Tribiology Int. 2009, 42, 1558-1564. [CrossRef]

30. Serre, E.; Boutin, Y.; Langevin, M.-E.; Lutin, F.; Pedneault, K.; Lacour, S.; Bazinet, L. Deacidification of cranberry juice protects against disruption of in-vitro intestinal cell barrier integrity. J. Funct. Foods 2016, 26, 208-216. [CrossRef]

31. Renaud, V.; Faucher, M.; Perreault, V.; Serre, E.; Dubé, P.; Boutin, Y.; Bazinet, L. Evolution of cranberry juice compounds during in vitro digestion and identification of the organic acid responsible for the disruption of in vitro intestinal cell barrier integrity. $J$. Food Sci. Technol. 2020, 57, 2329-2342. [CrossRef]

32. AOAC Acidity (Titratable) of Fruit Products. In AOAC Official Methods of Analysis; AOAC: Rockville City, MD, USA, 2000.

33. AOAC Quinic, malic, and Citric Acids in Cranberry Juice Cocktail and Apple Juice. In AOAC Official Methods of Analysis; AOAC: Rockville City, MD, USA, 2010.

34. Wu, X.; Prior, R.L. Systematic Identification and characterization of anthocyanins by HPLC-ESI-MS/MS in common foods in the United States : Fruits and berries. J. Agric. Food Chem. 2005, 53, 2589-2599. [CrossRef]

35. Khanal, R.C.; Howard, L.R.; Brownmiller, C.R.; Prior, R.L. Influence of extrusion processing on procyanidin composition and total anthocyanin contents of blueberry pomace. J. Food Sci. 2009, 74, 52-58. [CrossRef] [PubMed]

36. Singleton, V.L.; Rossi, J.A. Colorimetry of total phenolics with phosphomolybdic-phosphotungstic acid reagents. Am. J. Enol. Vitic. 1965, 16, 144-158. 
37. Fournier, E. Colorimetric quantification of carbohydrates. Curr. Protoc. Food Anal. Chem. 2001, E1.1.1-E1.1.8. [CrossRef]

38. AFNOR NF EN 1040 Chemical Disinfectants and Antiseptics-Quantitative Suspension Test for the Evaluation of Basic Bactericidal Activity of Chemical Disinfectants and Antiseptics-Test Method and Requirements (Phase 1); AFNOR: La PLaine Saint-Denis, France, 2006.

39. Shahzad, M.; Millhouse, E.; Culshaw, S.; Edwards, C.A.; Ramage, G.; Combet, E. Selected dietary (poly)phenols inhibit periodontal pathogen growth and biofilm formation. Food Funct. 2015, 6, 719-729. [CrossRef] [PubMed]

40. Madhwani, T.; McBain, A.J. Bacteriological effects of a Lactobacillus reuteri probiotic on in vitro oral biofilms. Arch. Oral Biol. 2011, 56, 1264-1273. [CrossRef]

41. Ben Lagha, A.; Groeger, S.; Meyle, J.; Grenier, D. Green tea polyphenols enhance gingival keratinocyte integrity and protect against invasion by Porphyromonas gingivalis. Pathog. Dis. 2018, 76, 1-9. [CrossRef]

42. Groeger, S.; Michel, J.; Meyle, J. Establishment and characterization of immortalized human gingival keratinocyte cell lines. J. Periodontal Res. 2008, 43, 604-614. [CrossRef]

43. Gilchrist, E.P.; Moyer, P.; Shillitoe, E.J.; Clare, N.; Murrah, V.A. Establishment of a human polyclonal oral epithelial cell line. Oral Surg. Oral Med. Oral Pathol. Oral Radiol. Endod. 2000, 90, 340-347. [CrossRef]

44. Svensäter, G.; Larsson, U.-B.; Greif, E.C.G.; Cvitkovitch, D.G.; Hamilton, I.R. Acid tolerance response and survival by oral bacteria. Oral Microbiol. Immunol. 1997, 12, 266-273. [CrossRef]

45. Sheng, J.; Marquis, R.E. Enhanced acid resistance of oral streptococci at lethal $\mathrm{pH}$ values associated with acid-tolerant catabolism and with ATP synthase activity. FEMS Microbiol. Lett. 2006, 262, 93-98. [CrossRef]

46. Bender, G.R.; Sutton, S.V.; Marquis, R.E. Acid tolerance, proton permeabilities, and membrane ATPases of oral streptococci. Infect. Immun. 1986, 53, 331-338. [CrossRef]

47. Lemos, J.A.; Palmer, S.R.; Zeng, L.; Wen, Z.T.; Kajfasz, J.K.; Freires, I.A.; Abranches, J.; Brady, L.J. The biology of Streptococcus mutans. Microbiol. Spect. 2019, 7, 435-448. [CrossRef]

48. Guo, L.; McLean, J.S.; Lux, R.; He, X.; Shi, W. The well-coordinated linkage between acidogenicity and aciduricity via insoluble glucans on the surface of Streptococcus mutans. Sci. Rep. 2015, 5, 18015. [CrossRef] [PubMed]

49. Korithoski, B.; Krastel, K.; Cvitkovitch, D.G. Transport and metabolism of citrate by Streptococcus mutans. J. Bacteriol. 2005, 187, 4451-4456. [CrossRef]

50. Sheng, J.; Marquis, R.E. Malolactic fermentation by Streptococcus mutans. FEMS Microbiol. Lett. 2007, 272, 196-201. [CrossRef] [PubMed]

51. Sturr, M.G.; Marquis, R.E. Comparative acid tolerances and inhibitor sensitivities of isolated F-ATPases of oral lactic acid bacteria. Appl. Environ. Microbiol. 1992, 58, 2287-2291. [CrossRef] [PubMed]

52. Kranz, S.; Guellmar, A.; Olschowsky, P.; Tonndorf-Martini, S.; Heyder, M.; Pfister, W.; Reise, M.; Sigusch, B. Antimicrobial effect of natural berry juices on common oral pathogenic bacteria. Antibiotics 2020, 9, 533. [CrossRef]

53. Nascimento, M.M.; Lemos, A.C.; Abranches, J.; Gonçalves, R.B.; Burne, R.A. Adaptive acid tolerance response of Streptococcus sobrinus. J. Bacteriol. 2004, 186, 6383-6390. [CrossRef] [PubMed]

54. Martinez, A.R.; Abranches, J.; Kajfasz, J.K.; Lemos, J.A. Characterization of the Streptococcus sobrinus acid-stress response by interspecies microarrays and proteomics. Mol. Oral Microbiol. 2010, 25, 331-342. [CrossRef] [PubMed]

55. Burne, R.A.; Marquis, R.E. Alkali production by oral bacteria and protection against dental caries. FEMS Microbiol. Lett. 2000, 193, 1-6. [CrossRef] [PubMed]

56. Casiano-Colón, A.; Marquis, R.E. Role of the arginine deiminase system in protecting oral bacteria and an enzymatic basis for acid tolerance. Appl. Environ. Microbiol. 1988, 54, 1318-1324. [CrossRef]

57. Chen, Y.Y.; Burne, R.A. Analysis of Streptococcus salivarius urease expression using continuous chemostat culture. FEMS Microbiol. Lett. 1996, 135, 223-229. [CrossRef]

58. Gilmore, K.S.; Srinivas, P.; Akins, D.R.; Hatter, K.L.; Gilmore, M.S. Growth, development, and gene expression in a persistent Streptococcus gordonii biofilm. Infect. Immun. 2003, 71, 4759-4766. [CrossRef] [PubMed]

59. Steinberg, D.; Feldman, M.; Ofek, I.; Weiss, E.I. Cranberry high molecular weight constituents promote Streptococcus sobrinus desorption from artificial biofilm. Int. J. Antimicrob. Agents 2005, 25, 247-251. [CrossRef] [PubMed]

60. McNee, S.G.; Geddes, D.A.M.; Weetman, D.A. Diffusion of sugars and acids in human dental plaque in vitro. Arch. Oral Biol. 1982, 27, 975-979. [CrossRef]

61. Stewart, P.S. A review of experimental measurements of effective diffusive permeabilities and effective diffusion coefficients in biofilms. Biotechnol. Bioeng. 1998, 59, 261-272. [CrossRef]

62. Souza, J.G.S.; Bertolini, M.; Thompson, A.; Mansfield, J.M.; Grassmann, A.A.; Maas, K.; Caimano, M.J.; Barao, V.A.R.; Vickerman, M.M.; Dongari-Bagtzoglou, A. Role of glucosyltransferase R in biofilm interactions between Streptococcus oralis and Candida albicans. ISME J. 2020, 14, 1207-1222. [CrossRef]

63. Hannig, C.; Sorg, J.; Spitzmüller, B.; Hannig, M.; Al-Ahmad, A. Polyphenolic beverages reduce initial bacterial adherence to enamel in situ. J. Dent. 2009, 37, 560-566. [CrossRef]

64. Weiss, E.I.; Kozlovsky, A.; Steinberg, D.; Lev-dor, R.; Bar, R.; Greenstein, N.; Feldman, M.; Sharon, N.; Ofek, I. A high molecular mass cranberry constituent reduces mutans streptococci level in saliva and inhibits in vitro adhesion to hydroxyapatite. FEMS Microbiol. Lett. 2004, 232, 89-92. [CrossRef]

65. Cowan, M.M.; Taylor, K.G.; Doyle, R.J. Role of sialic acid in the kinetics of Streptococcus sanguis adhesion to artificial pellicle. Infect. Immun. 1987, 55, 1552-1557. [CrossRef] 
66. Rozen, R.; Bachrach, G.; Bronshteyn, M.; Gedalia, I.; Steinberg, D. The role of fructans on dental biofilm formation by Streptococcus sobrinus, Streptococcus mutans, Streptococcus gordonii and Actinomyces viscosus. FEMS Microbiol. Lett. 2001, 195, 205-210. [CrossRef]

67. Singh, A.K.; Woodiga, S.A.; Grau, M.A.; King, S.J. Streptococcus oralis neuraminidase modulates adherence to multiple carbohydrates on platelets. Infect. Immun. 2017, 85, e00774-16. [CrossRef] [PubMed]

68. Ruhl, S.; Sandberg, A.L.; Cisar, J.O. Salivary receptors for the proline-rich protein-binding and lectin-like adhesins of oral actinomyces and streptococci. J. Dent. Res. 2004, 83, 505-510. [CrossRef] [PubMed]

69. Couvigny, B.; Kulakauskas, S.; Pons, N.; Quinquis, B.; Abraham, A.-L.; Meylheuc, T.; Delorme, C.; Renault, P.; Briandet, R.; Lapaque, N.; et al. Identification of new factors modulating adhesion abilities of the pioneer commensal bacterium Streptococcus salivarius. Front. Microbiol. 2018, 9, 273. [CrossRef] [PubMed]

70. Okada, H.; Yamazaki, I.; Yashiki, T.; Mima, H. Vaginal absorption of a potent luteinizing hormone-releasing hormone analogue (leuprolide) in rats II: Mechanism of absorption enhancement with organic acids. J. Pharm. Sci. 1983, 72, 75-78. [CrossRef]

71. Cho, M.J.; Scieszka, J.F.; Burton, P.S. Citric acid as an adjuvant for transepithelial transport. Int. J. Pharm. 1989, 52, 79-81. [CrossRef]

72. Siliciano, J.D.; Goodenough, D.A. Localization of the tight junction protein, ZO-1, is modulated by extracellular calcium and cell-cell contact in Madin-Darby canine kidney epithelial cells. J. Cell Biol. 1988, 107, 2389-2399. [CrossRef]

73. Yu, Q.; Wang, Z.; Li, P.; Yang, Q. The effect of various absorption enhancers on tight junction in the human intestinal Caco-2 cell line. Drug Dev. Ind. Pharm. 2013, 39, 587-592. [CrossRef]

74. Mongelli-Sabino, B.M.; Canuto, L.P.; Collares-Buzato, C.B. Acute and chronic exposure to high levels of glucose modulates tight junction-associated epithelial barrier function in a renal tubular cell line. Life Sci. 2017, 188, 149-157. [CrossRef]

75. Oyama, Y.; Yamano, H.; Ohkuma, A.; Ogawara, K.; Higaki, K.; Kimura, T. Carrier-mediated transport systems for glucose in mucosal cells of the human oral cavity. J. Pharm. Sci. 1999, 88, 830-834. [CrossRef]

76. Santaguida, S.; Janigro, D.; Hossain, M.; Oby, E.; Rapp, E.; Cucullo, L. Side by side comparison between dynamic versus static models of blood-brain barrier in vitro: A permeability study. Brain Res. 2006, 1109, 1-13. [CrossRef]

77. Ramadan, Q.; Jing, L. Characterization of tight junction disruption and immune response modulation in a miniaturized Caco2/U937 coculture-based in vitro model of the human intestinal barrier. Biomed. Microdevices 2016, 18, 11. [CrossRef]

78. Dawes, C. Factors Influencing Salivary Flow Rate and Composition. In Saliva and Oral Health, 4th ed.; Edgar, W.M., Dawes, C., O'Mullane, D.M., Eds.; Stephen Hancocks Limited: London, UK, 2012; pp. 37-56; ISBN 978-0-9565668-3-6.

79. Held, S.; Schieberle, P.; Somoza, V. Characterization of alpha-terpineol as an anti-inflammatory component of orange juice by in vitro studies using oral buccal cells. J. Agric. Food Chem. 2007, 55, 8040-8046. [CrossRef]

80. Grauso, M.; Lan, A.; Andriamihaja, M.; Bouillaud, F.; Blachier, F. Hyperosmolar environment and intestinal epithelial cells: Impact on mitochondrial oxygen consumption, proliferation, and barrier function in vitro. Sci. Rep. 2019, 9, 11360. [CrossRef]

81. Lan, C.-C.E.; Wu, C.-S.; Huang, S.-M.; Wu, I.H.; Chen, G.-S. High-glucose environment enhanced oxidative stress and increased interleukin-8 secretion from keratinocytes: New insights into impaired diabetic wound healing. Diabetes 2013, 62, 2530-2538. [CrossRef] [PubMed] 